University of Tennessee College of Law

Legal Scholarship Repository: A Service of the Joel A. Katz Law Library

UTK Law Faculty Publications

2013

Mandating Precontractual Disclosure

Eric Franklin Amarante

Follow this and additional works at: https://ir.law.utk.edu/utklaw_facpubs

Part of the Law Commons 


\title{
MANDATING PRECONTRACTUAL DISCLOSURE
}

\author{
Eric H. Franklin ${ }^{*}$
}

\begin{abstract}
Parties negotiating an arm's length contract are generally not required to disclose facts to one another. Although this default rule is supported by both centuries of common law and freedom of contract principles, courts and legislatures treat certain transactions differently. This is particularly true in circumstances in which the default rule results in an unacceptable harm suffered by a broad group of persons. In such cases, lawmakers have acted to impose precontractual disclosure obligations. These decisions and statutes are largely reactive: a harm is identified in a certain transaction's precontractual period and disclosure is mandated to rectify the harm. These reactive measures, although helpful, are insufficient in some instances. Large scale economic calamities are often caused by information asymmetries in individual contracts. This was true in the Great Depression (unregulated contracts for sales of stock) and the Great Recession (unregulated contracts for sales of mortgage-backed securities).

This article proposes an analytical tool to prospectively identify such transactions. This tool, the Disclosure Framework, provides lawmakers a means of identifying circumstances in which it is appropriate to mandate precontractual disclosure. To accomplish this task, the Disclosure Framework directs lawmakers to identify the information asymmetry in a transaction and balance the respective harms of either disclosure or nondisclosure on the affected stakeholder group.

Precontractual disclosure is a matter of compelling immediacy. Because regulatory agencies are currently struggling with how to structure the disclosure mandates of the Dodd-Frank Wall Street Reform and Consumer Protection Act, the question of when it is appropriate to mandate precontractual disclosure is both timely and important. Although designed for legislators, the Disclosure Framework may also serve as a tool for consumer rights groups and agencies (such as the recently established Consumer Financial Protection Bureau) to help spur legislative action. Ultimately, the Disclosure Framework provides support for the imposition of precontractual disclosure that is both theoretically sound and consistent with common law and statutory exceptions to the default rule.
\end{abstract}

\footnotetext{
* Whiting Clinical Fellow, University of Denver Sturm College of Law. The author would like to thank Robert Hillman, Jay Brown, Nancy Leong, Viva Moffat, Mohsen Manesh, Tammy Kuennen, Brittany Glidden, Kevin Lynch, Kyle Velte, Lindsey Webb, Chris Lasch, Ian Farrell, Bernard Chao, John Campbell, Justin Pidot, and Robin Walker-Sterling for their thoughtful comments. The author would also like to thank the participants of the 2011 Clinical Law Review Writers' Workshop, the Domestic and International Law work in progress session of the 2012 AALS Conference on Clinical Education, the Consumers, Contracts, and Children work in progress session of the 2011 AALS Conference on Clinical Education, and the Seventh Annual International Contracts Conference. Excellent research assistance was provided by Cara Owen (J.D. expected 2013), Andrew McFadden (J.D. expected 2014), and Jonathan Saadeh (J.D. expected 2014). Finally, the author owes an immeasurable debt of gratitude to Patience Crowder for her tireless and selfless support.
} 


\section{TABLE OF CONTENTS}

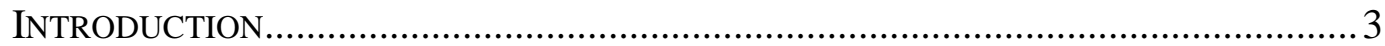

I. INFORMATION ASYMMETRY AND THE LIMITS OF FREEDOM OF CONTRACT ..........6

A. No Duty of Precontractual Disclosure ..................................................... 6

B. Freedom of Contract ......................................................................... 8

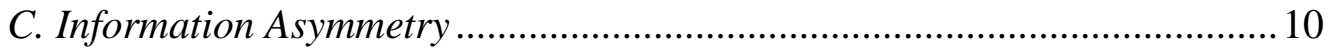

1. Freedom of Contract and Information Symmetry .......................... 11

2. Eliminating Information Asymmetry Supports Freedom of

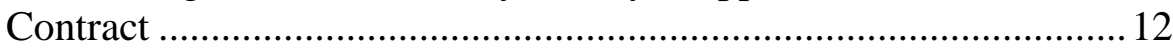

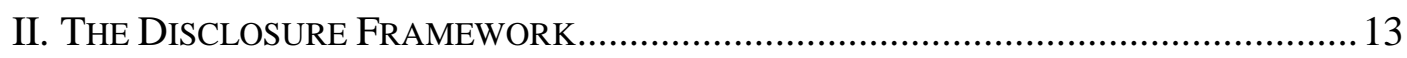

A. Step One: The Information Asymmetry Analysis ..................................... 14

B. Step Two: The Stakeholder Analysis ....................................................... 15

III. THE BASIS OF THE DisClOSURE FRAMEWORK: EXCEPTIONS TO THE RULE AGAinst PRECONTRACTUAL DisClOSURE ................................................... 17

A. Common Law Exceptions to the General Rule ........................................... 17

1. Precontractual Disclosure in Marine Insurance Contracts ................19

2. The Marine Insurance Information Asymmetry Analysis ................21

3. The Marine Insurance Stakeholder Analysis...................................223

B. A Federal Statutory Exception to the General Rule .................................... 24

1. The Regulation of Private Sales of Securities ................................. 24

2. The Private Sale of Securities Information Asymmetry

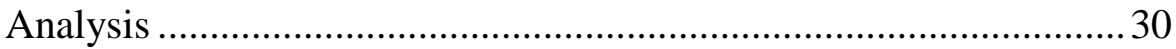

3. The Private Sale of Securities Stakeholder Analysis ...................... 31

C. A Statutory-Common Law Hybrid Exception to the General Rule .............. 32

1. Precontractual Disclosure in Private Home Sales ............................ 32

2. Motivation for the California Statutes ........................................... 33

3. The California Statutes and the Disclosure Framework ....................35

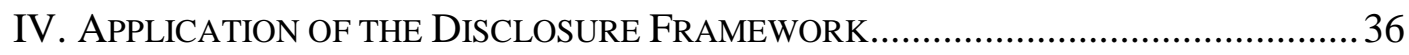

A. The Student Loan Problem ..................................................................... 36

1. “[W]hen I graduate, I'm going to owe like $\$ 900$ a month. No

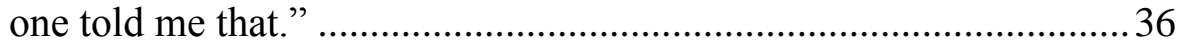

2. The Shopping Sheet: A Potential Solution ...................................... 38

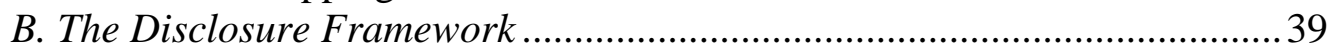

1. The Student Loan Information Asymmetry Analysis .......................39

2. The Student Loan Stakeholder Analysis ..........................................4 41

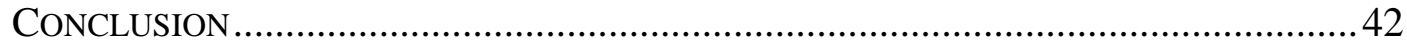




\section{INTRODUCTION}

Let me take you back in time. Imagine you are a high school senior. ${ }^{1}$ You have spent the previous three years getting good grades, taking admissions tests, and writing personal statements. The hard work has paid off, and several colleges have accepted you. You have narrowed the choice to two, but no matter how hard you try, you cannot choose. You see no discernible difference in reputation or academic offerings, and you would happily live in either school's location. In fact, the only meaningful distinguishing factor that you can discern is tuition. One school is significantly cheaper. However, you suspect that this difference might be offset by living expenses; the cheaper school is in New York City, and the more expensive school is in a small rural town.

To help make your decision, one of the schools provided a financial aid award letter that lists a tremendous amount of information in a clear, easily understood format. Such information includes your estimated expenses, the amount most students borrow to attend the school, the rate of graduates that ultimately default on their loans, and an estimated monthly loan payment. ${ }^{2}$

This is a fantastic tool, so you naturally ask the other school to provide a similar letter. After all, you are not making this decision in a vacuum, and you will only be able to make an informed decision if you can put the proffered data in perspective. Unfortunately, the other school refuses to provide the information. ${ }^{3}$

You find it disconcerting that schools expect you to sign a contract obligating you to hundreds of thousands of dollars of debt without knowing all the relevant information. However frustrating, for many transactions, contract law does not prohibit the school's behavior. Indeed, generally speaking, as long as the school neither lies nor knowingly allows you to rely on a falsehood, ${ }^{4}$ contract law does not view the school's behavior as

\footnotetext{
${ }^{1}$ If this is a bridge too far, the exercise also works if you imagine yourself a parent of a high school senior.

${ }^{2}$ You learn that this financial aid award letter was based upon a model letter, otherwise known as the "Shopping Sheet," created by a partnership between the Consumer Financial Protection Bureau and the Department of Education to address the rising costs of education by helping students "know before they owe." See Richard Cordray, Director of the Consumer Financial Protection Bureau, Remarks in a Press Call with Education Secretary Arne Duncan: Financial Aid Shopping Sheet (July 23, 2012).

${ }^{3}$ At the time of this writing, the Shopping Sheet is largely voluntary for schools. To date, ten schools have pledged to use the Shopping Sheet. See Press Release, U.S. Dep't of Educ., Obama Administration and the Consumer Financial Protection Bureau Partner to Promote Transparency in College Costs (July 24, 2012).

${ }^{4}$ See RESTATEMENT (SECOND) OF CONTRACTS $\$ 161$ (1981); see also infra notes 61-66 and accompanying text.
} 
inappropriate. ${ }^{5}$ However, absent clear violations such as fraud or misrepresentation, how should parties conduct themselves before a contract is executed? Is passive honesty enough, or do we owe positive disclosure obligations to our contracting counterparts? More to the point, when is it appropriate to impose a duty to disclose material facts upon parties contemplating a contractual relationship?

The general rule is that parties do not owe one another any duty of disclosure before a contract is in place. In certain circumstances, both common law and statutory law have deviated from this general rule. However, these decisions and statutes are largely reactive: an inefficiency is identified in a certain transaction's precontractual period and disclosure is mandated to remedy such inefficiency. These reactive measures, although helpful, are insufficient. Ideally, lawmakers could identify such problems in a more proactive manner, as inefficiencies in many contractual relationships have negative effects that extend beyond the contracting parties. For example, some have argued that the Great Recession would have been mitigated (or avoided altogether) if the financial industry were subject to mandates of greater disclosure. ${ }^{6}$ Therefore, it should be no surprise that

\footnotetext{
${ }^{5}$ Nicola W. Palmieri, Good Faith Disclosures Required During Precontractual Negotiations, 24 Seton HaLl L. REV. 70, 84 (1993) (noting that "the United States Supreme Court opined that a buyer who had exclusive information, which was about to be made public and that would substantially affect the price of a commodity, was not required to inform the seller as long as the buyer did nothing to deceive the seller."); see also Laidlaw v. Organ, 15 U.S. (2 Wheat.) 178, 193 (1817) (noting that " $[\mathrm{t}]$ he question in this case is, whether the intelligence of [material] extrinsic circumstances ... which was exclusively within the knowledge of [one party], ought to have been communicated by him to the [other party]? The court is of the opinion that he was not bound to communicate it."); Mkt. St. Assocs. v. Frey, 941 F.2d 588, 594 (7th Cir. 1991); Frigitemp Corp. v. Fin. Dynamics Fund, Inc., 524 F.2d 275, 282-83 (2nd Cir. 1975); Anthony T. Kronman, Mistake, Disclosure, Information, and the Law of Contracts, 7 J. LEGAL STUD. 1 (1978). ${ }^{6}$ Although the blame for the Great Recession may be placed upon many industries and players, there is little doubt that predatory lending (spurred on by the securitization of mortgages) played a major role. See Nick Carey, Racial predatory loans fueled U.S. housing crisis: study, REUTERS, (Oct. 4, 2010), http://www.reuters.com/article/2010/10/04/us-usa-foreclosures-raceidUSTRE6930K520101004 (citing Jacob S. Rugh \& Douglas S. Massey, Racial Segregation and the American Foreclosure Crisis, 75 AM. SocIOLOGICAL REV. 629 (2010) ("Predatory lending aimed at racially segregated minority neighborhoods led to mass foreclosures that fueled the U.S. housing crisis.")). The primary weapon to combat predatory lending is mandated disclosures. See, e.g., About Predatory Lending, WASH. STATE DEP'T OF FIN. INSTS., (Dec. 15, 2010) http://www.dfi.wa.gov/consumers/predlendwp.htm (emphasizing the importance of disclosures in avoiding predatory lending by noting that "disclosures are required to be provided at two major points in the mortgage transaction. If disclosures are not provided [at these two points], do not do business with this lender or broker."). Beyond predatory lending, disclosures are the focus of legislation attempting to prevent future economic
} 
precontractual disclosure is a core component of many of the mandates of the statute enacted to address the Great Recession, the Dodd-Frank Wall Street Reform and Consumer Protection Act (the "Dodd-Frank Act"). Given that regulatory agencies are currently struggling with how to structure the disclosure mandates of the Dodd-Frank Act (especially in the area of securities and securitization reform), ${ }^{8}$ the question of when it is appropriate to mandate precontractual disclosure is a matter of compelling immediacy.

This article proposes an analytical framework for legislators to identify when it is appropriate to mandate precontractual disclosure. Both common law and statutory law have established exceptions to the general rule against precontractual disclosure. Despite the fact that these exceptions have a narrow focus and are tailored to apply to a particular fact pattern, they share some similarities. These similarities provide the basis to craft universallyapplicable principles, which this article uses to create the legislative framework for establishing the appropriateness of precontractual disclosure. This framework has two factors: an analysis of information asymmetry in the contractual relationship at issue and the impact of the transaction on certain stakeholders. This article calls this proposed analytical framework the Disclosure Framework. The Disclosure Framework, properly applied, serves as a guide for legislators considering the imposition of disclosure requirements.

As background, Part I of this article discusses the default rule: parties to a negotiation do not owe one another a duty of precontractual disclosure.

crises. For example, the Dodd-Frank Wall Street Reform and Consumer Protection Act's preamble states that a goal of the act is to "improve ... transparency in the financial system.” Pub. L. No. 111-203, 124 Stat. 1377 (2010) [hereinafter Dodd-Frank Act]; see also, Halah Touryalai, Jamie Dimon's Testimony: Volcker Rule May Have Prevented Loss, FORBES, Jun. 13, 2012, (noting that Jamie Dimon, chief executive and chairman of JPMorgan Chase, "says regulators should make sure there are ... proper disclosures...."). It should be noted, however, that some commentators do not believe that mandating disclosure helps ameliorate the targeted issues. See, e.g., Omri Ben-Shahar and Carl E. Schneider, The Failure of Mandated Disclosure, 159 PENN. L.R. 647, 653 (2011), pointing out that mandated disclosures are often impenetrable.

${ }^{7}$ See, e.g., Dodd-Frank Act $\S 1100$ F (amending section 615(h) of the Fair Credit Reporting Act to require certain disclosures if a credit score is used in making the credit decision); see also Dodd-Frank Act, Title IX, Subtitle C (requiring disclosures by credit rating agencies which include disclosure of conflicts of interest, historical rating performance data, and detailed rating methodologies).

${ }^{8}$ See, e.g., Enhanced Oversight After the Financial Crisis: The Wall Street Reform Act at One Year: Hearing Before the Senate Comm. on Banking, Hous. and Urban Affairs, 112 Congr. (2011) (statement of Mary L. Schapiro, Chairman, U.S. Securities and Exchange Commission) ("To help fulfill its objective, the [Dodd-Frank] Act directs the SEC to write a large number of rules necessary to implement the Act [including] more than 90 mandatory rulemaking provisions."). 
This section also explores the theoretical justification for the default rule, freedom of contract, before addressing how certain information asymmetries present problems for the default rule. Part II proposes and describes the two factors of the Disclosure Framework: the analysis of information asymmetry in the contractual relationship at issue and an analysis of the stakeholder interest in imposing precontractual disclosure in the target transaction. Part III discusses both common law and statutory exceptions to the default rule against precontractual disclosure, drawing parallels between these exceptions and revealing how these parallels are reflected in the Disclosure Framework's two factors. Part IV illustrates the application of the Disclosure Framework by analyzing the hypothetical described at this article's outset and discusses whether the Disclosure Framework analysis recommends precontractual disclosure in the student loan context.

\section{INFORMATION ASYMMETRY AND THE LIMITS OF FREEDOM OF CONTRACT ${ }^{9}$}

Before discussing the Disclosure Framework and identifying potential transactions in which the imposition of precontractual disclosure is appropriate, it is important to establish that the default rule does not require precontractual disclosure between contracting parties and to discuss the theoretical foundation of the default rule, freedom of contract. This section will then address the problem with the default rule, which is that most contractual relationships suffer from information asymmetry, before exploring the nuanced balance at play between information asymmetry and freedom of contract.

\section{A. No Duty of Precontractual Disclosure}

In the absence of a statutory mandate regarding precontractual disclosure, one is tempted to look to the duty of good faith and fair dealing imposed upon all commercial transactions by the Uniform Commercial Code ("UCC") ${ }^{10}$ and the Restatement (Second) of Contracts

\footnotetext{
${ }^{9}$ This section's title pays homage to Michael Trebilcock's seminal work, THE LIMITS OF FREEDOM OF CONTRACT (1993).

${ }^{10}$ The UCC definitively states that "[e]very contract or duty [under the UCC] imposes an obligation of good faith in its performance or enforcement." See U.C.C. § 1-203 (2012).

The UCC has been adopted by every state. See Edward Lee, Warming up to UserGenerated Content, U. ILL. L. REV. 1459, 1465 (2008) (noting " $[\mathrm{t}]$ he universal adoption of the U.C.C. (at least in some form) by all fifty states"). The UCC has different standards of good faith for merchants. See Zipporah Wiseman, The Limits of Vision: Karl Llewellyn and the Merchant Rules, 100 HARV. L. REV. 465, 524 n. 258 (1987). However, this distinction has no bearing on the arguments of this article.
} 
("Restatement"). ${ }^{11}$ It is conceivable that the definition of good faith, the default rule that governs contracting parties, might include precontractual obligations. Unfortunately, neither the UCC nor the Restatement provides a particularly satisfying definition of "good faith."12 This failure is not peculiar to the drafters of the UCC or the Restatement, as the process of defining "good faith" has proven to be a frustrating endeavor and it remains a fairly nebulous concept. ${ }^{13}$ So much, in fact, that Professor Robert Summers has suggested that "the very idea of good faith ... is simply not the kind of idea that is susceptible of ... a definitional approach."14 Professor Summers continues to state that "[m]any commentators suggest they are willing to accept that good faith cannot, as such, be usefully defined in terms of a single, general, positive meaning." 15

Beyond definitional difficulties, even if the duty of good faith required some level of disclosure (a notion that is debatable), the duty of good faith would not govern any precontractual period. ${ }^{16}$ This is, perhaps, reasonable. Individuals enter into contracts on a near daily basis, and thus, in some sense, everyone is in a precontractual period at any given moment. At what point does an individual's consideration of a contractual relationship rise to a sufficient level to be considered precontractual? This issue may have convinced the drafters of the UCC and the Restatement to steer clear of any

${ }^{11}$ The Restatement, with similar conclusiveness, imposes upon each party a "duty of good faith and fair dealing in its performance and its enforcement." See RESTATEMENT (SECOND) OF CONTRACTS $§ 205$ (1981). The Restatement defines "good faith" as "faithfulness to an agreed common purpose and consistency with the justified expectations of the other party." Id. at cmt. A. For the purposes of this article, it is not important to determine if the UCC or the Restatement would apply to the transaction at issue.

12 The UCC defines "good faith" as "honesty in fact and the observance of reasonable commercial standards of fair dealing in the trade." U.C.C. § 1-203.

${ }^{13}$ See Robert S. Summers, The General Duty of Good Faith-its recognition and conceptualization, 67 CORNELL L. REV. 810, 818 (1982) (“[S]ome words and phrases do not have a general positive meaning of their own within the contexts or realms of discourse in which they are home.").

${ }^{14}$ Id. at 830 .

${ }^{15} \mathrm{Id}$. at 829 .

${ }^{16}$ Eric H. Holmes, A Contextual Study of Commercial Good Faith: Good-Faith Disclosure in Contract Formation, 39 U. PITT. L. REV. 381, 382, n.3 (1978) (noting that "the U.C.C. and the Restatement do not extend [good faith] to the bargaining stage of contract formation"). However, some scholars suggest that this is not necessarily the case. See Palmieri, supra note 5, at 70 (arguing that the exceptions to the general rule (that parties do not have a duty of precontractual disclosure) have rendered the general rule inapplicable); see also Alan M. Weinberger, Let the Buyer be Well Informed? - Doubting the Demise of Caveat Emptor, 55 MD. L. REV. 387, 389 (1996) (noting "the nationwide erosion of the common-law doctrine of caveat emptor in transactions in real property."). In addition, a minority of courts have held that the UCC requirement of good faith extends to negotiations. See, e.g., Connecticut Nat'l Bank v. Anderson, No. 0053810, 1991 WL

204359 (Conn. Super. Ct. Oct. 1, 1991). 
period in which a contract is not in place.

However, even if one were to clearly define the precontractual period (for example, as this article does, as the period beginning at the point in which a party evidences an intent to enter into a negotiation and ending upon either execution of a contract or a party ceasing negotiations) and impose good faith upon such period, it is not clear that the duty of good faith would impose a duty of disclosure. This is generally true even when one party knows something that the other party does not. This is justified largely by the theory of freedom of contract. ${ }^{17}$

\section{B. Freedom of Contract}

Freedom of contract has been described, with no intended hyperbole, as "the foundation of contract law." 18 Freedom of contract is, in the simplest of terms, the absolute right of parties to decide to contract (or not contract) with one another and to determine the terms of such contract. ${ }^{19}$ This theory places a primacy upon private ordering, and argues against outside regulation of contracts. The freedom of contract theory assumes that "contracts that support legitimate economic exchange are at least presumptively enforceable," 20 and posits that courts, legislators, and other regulators should generally avoid investigating such contracts. ${ }^{21}$ This is not only because regulation is an affront to the contracting parties' right to order their affairs, but also because of the assumption that parties will, if acting rationally, reach an agreement that represents the most efficient use of the respective parties' goods or services. ${ }^{22}$ In sum, freedom of contract is "the idea, fundamental in the orthodox understanding of contract law, that the content of a contractual obligation is a matter for the parties, not the

${ }^{17}$ Benjamin E. Hermalin, Avery W. Katz \& Richard Craswell, Contract Law \$2.2.1, in THE HANDBOOK OF LAW \& ECONOMICS (A. Mitchell Polinsky \& Steven Shavell eds., 2007) (noting that " $[\mathrm{t}]$ he threshold issue in any discussion of contract law is freedom of contract - the extent to which the law sanctions the use of contracts as a commitment device.").

${ }^{18}$ Robert A. Hillman, Contract Law in Context: The Case of Software Contracts, 45 WAKE FOREST L. REV. 669, 684 (2010).

${ }^{19}$ See Roberto Mangabeira Unger, The Critical Legal Studies Movement, 96 HARV. L. REV. 561, at 625 (1983). This theory "has two distinct dimensions: The first-freedom from contract-stipulates that persons should not have contractual obligations imposed on them without their consent. The second-freedom to contract-stipulates that persons should have the power to alter by consent their legal relations." Randy E. Barnett, Some Problems with Contract as Promise, 77 CORNELL L. REV. 1022, 1023-24 (1992).

${ }^{20}$ See Hermalin, et. al, supra note 17 , at $\$ 2,19$.

${ }^{21}$ See Michael J. Trebilcock, THE LIMITS OF FrEEDOM OF CONTRACT, 2-8 (1993).

${ }^{22}$ See Scott R. Peppet, Freedom of Contract in an Augmented Reality: The Case of Consumer Contracts, 59 UCLA L. REV. 676, 708 (2012). 
law.",23

As a normative theory, freedom of contract enjoys wide support. ${ }^{24}$ The economic justification for freedom of contract, for example, lies in the assumption that individuals will act in their own best interests, and third parties should therefore refrain from imposing their judgment upon a privately-ordered arrangement. ${ }^{25}$ In addition to the economic justification, support for freedom of contract also has a political justification, in that an individual's freedom to privately order his or her affairs places the highest value on such individual's consent (or for that matter, his or her right not to consent) to any given transaction. ${ }^{26}$ Freedom of contract adherents also cite a social justice justification, noting that the freedom of contract has the power to liberate parties from "traditional inequality and immobility" by giving each individual the equal right to freely determine the terms of his or her agreements. ${ }^{27}$ In addition, freedom of contract also enjoys the support of instrumentalists (arguing that freedom of contract results in the highest use of property) ${ }^{28}$ and moralists (arguing that freedom of contract supports the moral justifications for enforcing contracts). ${ }^{29}$

Despite the broad support in favor of freedom of contract, many of its justifications rely upon each party having a certain level of access to information. Equal access to information, however, is seldom found in contracting relationships. ${ }^{30}$ As discussed below, the existence of information asymmetry in many contracting relationships presents some problems for the freedom of contract theory.

${ }^{23}$ Stephen A. SMith, CONTRACt TheOry 59 (2004).

${ }^{24}$ As explained by Professor Robert Hillman, "the centrality of contractual freedom in American jurisprudence derives in part from society's fervent respect for individual freedom and strong faith in limited government." ROBERT A. HILLMAN, THE RICHNESS OF CONTRACT LAW, 9 (1997).

${ }^{25} I d$. This rather pithy statement belies the voluminous economic arguments laid out in favor of freedom of contract. For a more nuanced and complete discussion of the economic arguments in favor of freedom of contract, see Hermalin, et. al, supra note 17, at §2, 22.

${ }^{26}$ See Hillman, supra note 24 , at 8 (noting that "[p]rivate ordering is the quintessential form of government with the consent of the governed").

${ }^{27}$ See id. at 11 (quoting Wolfgang G. Friedmann, Some Reflections on Status and Freedom, in ESSAYS IN JURISPRUDENCE IN HONOR OF ROSCOE POUND 236 (1962)).

${ }^{28} I d$. (noting that "[f]ree contracting ... enables goods and services to move "from less to more valuable uses"” (quoting RICHARD A. POSNER, ECONOMIC ANALYSIS OF LAW, 79 (1986))).

${ }^{29} I d$. at 12 (noting that "the moral obligation from making a promise is the key to contract enforcement" (citing CHARLES FRIED, CONTRACT AS PROMISE: A THEORY OF CONTRACTUAL OBLIGATION (1981))). This is by no means an exhaustive list of the support for freedom of contract. For a more complete discussion, see Trebilcock, supra note 21, at 2-8.

${ }^{30}$ See infra note 32 and accompanying text. 


\section{Information Asymmetry}

Information asymmetry exists whenever a party to a contract does not enjoy the same level of access as such party's contracting counterpart. ${ }^{31}$ If each party enjoys equal access to the fact at issue, there is no need to require disclosure. However, equal access is rarely the case, and information asymmetry is the norm, not the exception. Practically every agreement will suffer from some imbalance in information because absolute information symmetry is virtually impossible to obtain. As illustrated by Professor Michael Trebilcock,

[a]lmost no exchanges are entered into with absolutely perfect information by both parties. Even the purchase of the morning newspaper in the local variety store on the assumption that it will contain an interesting film or restaurant review, when this assumption turns out to be false, reflects an exchange entered into with incomplete information. $^{32}$

This virtual ubiquity of information asymmetry may at first appear troubling. Intuitive notions of "fair play and due process" suggest that contracts where information asymmetry is great should not be enforceable. ${ }^{33}$ However, information asymmetry plays a vital function in the marketplace, and it should not be eliminated without good cause.

The primary defense of information asymmetry is economic. Information is not free. As such, an economically rational society should fashion a regulatory environment which rewards those who invest in information discovery. A familiar illustration of this argument is the hypothetical in which a prospector incurs various expenses to investigate a piece of farmland. After engaging in costly studies and measurements, the prospector determines there is a high likelihood of a precious mineral under the land. ${ }^{34}$ Upon this discovery, the prospector makes an offer to buy the land at a price based upon the land's use as farmland (i.e., without consideration of the value of the minerals). If the prospector's investigation proves correct and minerals exist under the land, the prospector would reap a great profit, thereby justifying the investigation's expense.

If a regulatory environment removed all information asymmetry, the

${ }^{31}$ See Trebilcock, supra note 21, at 102-26.

${ }^{32}$ See id. at 103.

${ }^{33}$ See Robert A. Hillman \& Maureen A. O'Rourke, Principles of the Law of Software Contracts: Some Highlights, 84 TuLANE L. REV. 1519, 1531 (2010) (noting that "due process requires 'fair warning,' which in the context of criminal law means that citizens can be punished only for violating laws on the books .... Yet we all know that people rarely read criminal statutes.").

${ }^{34}$ See Trebilcock, supra note 21 , at 108. 
prospector would not reap such benefit. If, for example, regulations required disclosure to remedy information symmetry in the hypothetical, the prospector would be forced to disclose the results of his investigation (the probability of minerals under the land), and the farmer, assuming economic rationality, would demand a higher price. This "effectively deprives [the prospector] of any economic return on his investments in acquiring the information." ${ }^{, 35}$ Thus, if mandatory disclosure were a default requirement, it is likely that the prospector would not engage in any investigation because of the related expenses. Ultimately, the minerals would not be discovered, the land would continue as farmland, and the highest possible economic use of the land would not be realized.

This hypothetical illustrates how information asymmetry provides an incentive for individuals to undertake the expenses of information collection. However, despite the argument that mandated disclosure might devalue information and may disincentivize both information gathering and the highest potential use of property, there are instances in which mandating disclosure is proper. This occurs when information asymmetries are so great that they challenge the justifications of freedom of contract and overcome the rationale of incentivizing information gathering.

\section{Freedom of Contract and Information Symmetry}

Pure freedom of contract theory promotes individual authority to structure and commit to agreements without regulatory burdens. But most freedom of contract justifications founder when faced with the reality of information asymmetry. This is because the natural consequences of information asymmetry undermine the freedom of contract justifications. For example, in the presence of an information imbalance, a party may agree to unanticipated inefficiencies (upsetting freedom of contract's assumption that the private arrangement is the best use of the parties' goods or services), ${ }^{36}$ enter into an agreement without fully contemplating the implications (undermining the purported political justifications of freedom of contract), ${ }^{37}$ or enter into an agreement with false assumptions of the exchanged value (virtually eliminating any chance that the agreement will serve freedom of contract's social justice purpose). ${ }^{38}$ These results are troubling to many freedom of contract adherents, as Professor Trebilcock notes, "[e]ven the most committed proponents of free markets and freedom of contract recognize that certain information preconditions" are required to

\footnotetext{
${ }^{35} \mathrm{Id}$. at 109.

${ }^{36}$ See Hillman, supra note 24, at 11.

${ }^{37} \mathrm{Id}$. at 8.

${ }^{38} \mathrm{Id}$. at 11.
} 
achieve freedom of contract's promised efficiencies. ${ }^{39}$

Despite these issues, some commentators argue that information asymmetry does not pose any problems for freedom of contract. Indeed, some argue that information asymmetry is as necessary as it is pervasive. This argument posits that a legal system which has eliminated all information asymmetries is a false utopia, promising potential peril. Professor Roberto Mangabeira Unger argues that "a commitment to cancel out every inequality of power or knowledge as soon as it arose would also undermine a contract system," explaining that

[r]eal markets are never just machines for instantaneous transactions among economic agents equally knowledgeable and equally able to await the next offer or to withdraw from current courses of dealing. Continued success in market transactions shows partly in the buildup of advantages of power or knowledge that enable their beneficiaries to do that much better in the next round of transactions. If everyone were quickly restored to a situation of equality within the market order, the method responsible for this restoration ... would empty market transactions of much of their apparent significance. ${ }^{40}$

Thus, Professor Unger argues that information asymmetries are not only a reality of markets, but are a necessity for market survival. ${ }^{41}$ From this perspective, elimination of information asymmetry would not only rob private actors of their right to privately order their agreements, but it would also prove disastrous to a market-based system.

\section{Eliminating Information Asymmetry Supports Freedom of Contract}

Professor Unger's arguments notwithstanding, certain information asymmetries pose problems for freedom of contract adherents because it belies the assumption that the parties are freely entering into a contract. For a theory with a basis in individual freedom, this presents a challenge. Information asymmetry in the contracting relationship "impairs one's ability to make decisions of the fully rational kind postulated in economic

\footnotetext{
${ }^{39}$ See Trebilcock, supra note 21, at 102. To make his point, Professor Trebilcock cites Milton Friedman's statement that " $[\mathrm{t}]$ he possibility of coordination through voluntary cooperation rests on the elementary - yet frequently denied - proposition that both parties to an economic transaction benefit from it, provided the transaction is bilaterally voluntary and informed."

${ }^{40}$ See Roberto Mangabeira Unger, The Critical Legal Studies Movement, 96 HARV. L. REV. 561, 626 (1983).

${ }^{41}$ See also Jay P. Kesan and Andres A. Gallo, Optimizing Regulation of Electronic Commerce, 72 U. CIN. L. REV. 1497, 1509 (2004).
} 
discourse." 42 In essence, a decision made without some minimum level of information will not support the efficiency arguments of freedom of contract because the party without such information did not, in effect, make a decision. Or as more succinctly posited by Professor Kim Lane Scheppele, information is a "precondition of choice." 43 Professor Scheppele continues to explain that "one needs a certain amount of information in order to be able to imagine one's alternatives, to understand enough of their implications to be able to distinguish among them, and to assess which one would best realize one's aims." 44 In other words, if information asymmetries have rendered it impossible for a party to make an informed decision, then such party enters into the contract without making a true choice. This "decision" to enter into a contract, therefore, is no decision at all, and is counter to freedom of contract principles. ${ }^{45}$

With all due respect to Professor Unger, this article adheres to Professor Scheppele's argument that some form of information balance is necessary to have true freedom of contract. This maxim suggests that a disclosure regime which selectively reduces information asymmetry is not necessarily counter to freedom of contract. By ensuring an equality of information in certain relationships, precontractual disclosure gives the contracting parties the right to make an informed decision concerning the agreement.

\section{THE DISCLOSURE FRAMEWORK}

Given the threats posed by information asymmetry, it should not be surprising that courts and legislatures have often departed from the general rule against any duty of precontractual disclosure. Common law disclosure obligations have been established by more than two centuries of case law, and statutory disclosure obligations can be found in some of the most fundamental of regulatory statutes. These exceptions serve as proof that the general rule against mandated disclosure is not appropriate in all circumstances. At first blush, these exceptions to the general rule appear fact-specific and narrow. However, upon closer inspection, the exceptions have similarities that may be distilled into general principles, which may be used to craft a more universal rule. This universal rule, explained in more detail below, serves as an analytical framework for legislators to use when considering the imposition of precontractual disclosure upon a particular relationship. This framework involves first analyzing the information

\footnotetext{
${ }^{42}$ EJAN MACKAAY, ECONOMICS OF INFORMATION AND LAW 107 (1980).

${ }^{43}$ Kim LANE SCHEPPELE, LEgAL SECRETS: EQUALITY AND EFFICIENCY IN THE COMMON LAW 25 (1988).

${ }^{44} I d$.

${ }^{45}$ See supra note 33 and accompanying text.
} 
asymmetry in the contractual relationship and then identifying and weighing the stakeholder interest in promoting precontractual disclosure in the particular transaction (the "Disclosure Framework").

\section{A. Step One: The Information Asymmetry Analysis}

The first step of the Disclosure Framework is an analysis of the information asymmetry between the contracting parties. Generally speaking, the focus of this analysis is on the ability of the parties to access the fact to be disclosed. This factor has an intuitive appeal: if a fact is readily accessible to both parties, where is the need for mandated disclosure? Indeed, if a material fact is neither in the sole possession of a party nor difficult for either party to unveil, then a compelling argument to require disclosure is difficult to make. ${ }^{46}$

At the other extreme, the mere existence of information asymmetry should not satisfy the first step of the Disclosure Framework because information asymmetry exists at some level in virtually every contractual relationship. ${ }^{47}$ Given this near ubiquity, the first step would be an irrelevant formality if any amount of information asymmetry satisfied the inquiry. Rather, this analysis uses a modified version of the equal access analysis proposed by Professor Scheppele. As set forth by Professor Scheppele, the inquiry relies upon the parties' equal access to material information. Equal access exists when the parties have "equal probabilities of finding the information if they put in the same level of effort." 48 As explained by Professor Scheppele,

two people would be said to have equal access to today's headlines because each could buy a newspaper, turn on the radio, watch the television, or listen to a conversation on the street. Given equal levels of effort, the two people could probably discover the news.... This does not mean that the two people would have the same information (one may prefer to listen to a baseball game; another may have too many

\footnotetext{
${ }^{46}$ See Palmieri, supra note 5, at 76 (noting that a duty of precontractual disclosure "does not mean to suggest that the parties ought to forgo their own independent investigation of the facts. While an investigation may impact on the duty of disclosure, it is always advisable to be as informed as possible before entering any transaction.").

${ }^{47}$ See Trebilcock, supra note 21 , at 103.

${ }^{48}$ See SCHEPPELE, supra note 43, at 120. The first step in the Disclosure Analysis does not include Professor Scheppele's inquiry into the capability of each party to expend the equivalent level of effort. This is not intended to devalue this step, but is rather to maintain the focus on the operative inquiry for the Disclosure Analysis: equal probability of discovery given equal effort expended. Capability of the parties is certainly an issue, but not one addressed by this article.
} 
other obligations to pay much attention to the news). But should each actor want to know the news, each would have to put in roughly the same effort to acquire it.... Equal access does not require that effort will always be successful; it only requires that equal effort is rewarded with equal probabilities of success. $^{49}$

In situations in which the contracting parties do not have such equal access, the information asymmetry is high enough to justify moving on to the second step of the Disclosure Framework, the stakeholder analysis.

\section{B. Step Two: The Stakeholder Analysis}

As noted above, information asymmetry will exist, at some level, in virtually every contractual relationship. Even when limited by the first step of the Disclosure Analysis, many contracting relationships will suffer from some level of information asymmetry. Some of these relationships are not ideal candidates for imposing precontractual disclosure (if, for example, the information asymmetries in such relationships support freedom of contract principles). Thus, the Disclosure Framework requires a limiting principle to specifically identify the instances of information asymmetry which are counter to freedom of contract. This principle must operate to limit the application of the Disclosure Framework when, despite the information asymmetry in a particular contractual relationship, there is not a strong enough public interest in imposing precontractual disclosure. This limiting principle directly addresses whether lawmakers are the proper actors to require precontractual disclosure. In other words, the inquiry is whether the transaction is "so far affected with a public interest as to justify legislative regulation." 50

Of course, before one can weigh the public interest, ${ }^{51}$ one must settle upon a definition. Unfortunately, the definition of public interest is neither obvious nor self-evident. Rather, public interest is a malleable ${ }^{52}$ concept

${ }^{49}$ Id. Professor Scheppele continues to state that “[o]ne person's lucky break does not interfere with equal access as long as the other person with whom she deals has faced the same chance of a fortuitous fate."

${ }^{50}$ German Alliance Ins. Co. v. Lewis, 233 U.S. 389, 406 (1914).

${ }^{51}$ The case law that weighs public interest is not exceedingly helpful. See, e.g., Northeast Utils. Serv. Co. v. F.E.R.C., 55 F.3d 686, 692 (1st Cir. 1995), which states rather cryptically, presumably in an attempt to clarify the proper means to weigh the public interest, that "[i]t all depends on whose ox is gored and how the public interest is affected."

${ }^{52}$ Karen O’Connor \& Lee Epstein, Paper Presentation at Midwest Political Science Association: Ties That Bind: Defining the Public Interest, Stage One, (April 12-14, 1984) ("The concept of public interest is elusive. Most have not attempted to define the term and those who have have been apologetic for their efforts."). 
often molded to match to the desires of the speaker. ${ }^{53}$ One may be tempted to resort to the definition proposed by Black's Law Dictionary, which confidently states that public interest is "[t]he general welfare of the public that warrants recognition and protection." 54 This definition, however, fails to provide a reliable manner in which to weigh public interest. After all, the "general welfare of the public" is ever-present, albeit in differing degrees. Indeed, the Supreme Court has suggested that "the public interest is concerned in every transaction between men," and that it permeates "the sum of the transactions constituting the activities of life." 55 To put a finer point on it, the definition of "public interest" often turns on context.

For purposes of the Disclosure Framework, this article adopts a stakeholder-based definition of public interest. ${ }^{56}$ Under this approach, before it is appropriate to impose precontractual disclosure obligations, one must identify the relevant stakeholders by determining the parties who are directly affected by the transaction. Once identified, the interest of the stakeholder group must be weighed against the interest of the contracting parties to define the contours of their agreement.

It is important to note that the only pertinent stakeholder interest for this factor of the Disclosure Framework is an interest in encouraging precontractual disclosure. Any other articulated interest will not suffice. The target transaction is, after all, a private agreement between private parties, and lawmakers should not lightly intervene in such transactions. ${ }^{57}$ Or as stated by Professor Lenore Weitzman, "unless some countervailing interest must come into account which would be sacrificed in the process, it would seem that the individual interest in promised advantages should be secured to the full extent of what has been assured him by the deliberate promise of another." 58 This countervailing interest is the stakeholder group's interest in promoting precontractual disclosure in the transaction-that is, the stakeholder group's interest in increasing efficiency in the transaction by reducing information asymmetry. Put another way, the stakeholder interest is great enough to satisfy the second step of the Disclosure Framework when the interests of third-party stakeholders in encouraging efficiency in the transaction significantly outweigh the interests of the contracting parties' desire to use information asymmetries as negotiating leverage.

\footnotetext{
${ }^{53}$ Envtl. Prot. Agency v. Mink, 410 U.S. 73, 81-82 (1973) (“The phrase 'public interest' ... has been subject to conflicting interpretations, often colored by personal prejudices and predilections.").

54 BLACK's LAW DictionARY 1266 (8th ed. 2004).

${ }^{55}$ German Alliance, 233 U.S. at 406.

56 This approach is, in part, identified by taking cues from the precontractual disclosure statutes discussed below. See infra Section III.

57 See Lenore J. WeitzMan, The MARriage Contract, 137 (1981).

${ }^{58} \mathrm{Id}$.
} 
The first step in the stakeholder analysis is identifying all parties that are directly affected by the transaction that have an interest in promoting precontractual disclosure in the transaction. These parties make up the stakeholder group. The next step is to weigh (i) the costs suffered by the stakeholder group if precontractual disclosure were not imposed against (ii) the costs suffered by the party forced to disclose. ${ }^{59}$ As with other concepts that pose definitional difficulties, ${ }^{60}$ it might be more illuminating to explain this factor by discussing examples.

\section{THE BASIS OF THE DISCLOSURE FRAMEWORK: EXCEPTIONS TO THE RULE AgAinst PRECONTRACTUAL Disclosure}

The default rule against the imposition of precontractual disclosure has many exceptions. These exceptions, whether imposed by courts or legislators, exhibit similarities which provide a foundation for the Disclosure Framework. As discussed in this section, each exception justifies precontractual disclosure because the transaction at issue suffered from an information asymmetry (i.e., the parties did not enjoy equal access to the fact to be disclosed), and the harm suffered by the stakeholder group due to nondisclosure outweighed the harm suffered by the party forced to disclose. In other words, each of the exceptions to the default rule meets the requirements of the two factors of the Disclosure Framework. The discussion in this section will prove that the Disclosure Framework is not only theoretically sound, but is also consistent with current statutory and common law departures from the default rule. This section will discuss a common law exception (the imposition of precontractual disclosure in marine insurance contracts), a federal statutory exception (the precontractual disclosures required in certain sales of private securities), and an exception first addressed by courts and later codified by a state legislature (the duty of a seller or broker to disclose certain facts to a potential home buyer).

\section{A. Common Law Exceptions to the General Rule}

The general rule that there is no duty of precontractual disclosure has a

\footnotetext{
${ }^{59}$ It may be apparent that this prong of the Disclosure Framework is not immune to manipulation. Clearly, the impact upon stakeholders is highly dependent on both how one defines a stakeholder and how one measures the transaction's impact upon such stakeholders. The specter of manipulation, however, should not cast doubt upon the utility of the Disclosure Framework. Given that this test is proposed for use by lawmakers, some flexibility in its applicability is ideal.

${ }^{60}$ See supra notes $12-15$ and accompanying text.
} 
number of common law exceptions. ${ }^{61}$ These exceptions include a duty to disclose facts (i) to avoid active concealment; ${ }^{62}$ (ii) to correct previously made material representations; ${ }^{63}$ (iii) to ensure that any disclosures voluntarily given are complete and full; ${ }^{64}$ (iv) in certain special relationships; ${ }^{65}$ and (v) to ensure a party is not acting upon a mistaken understanding of such information. ${ }^{66}$ In addition to these exceptions, courts have imposed a duty of precontractual disclosure in certain industries. This section focuses on the oldest example of a common law imposition of precontractual disclosure, the judicially-imposed duty to disclose material facts in marine insurance contracts. Analysis of this duty will illustrate that the common law justifications for imposing precontractual disclosure in marine insurance contracts mirror the factors of the Disclosure Framework: information asymmetry and a strong stakeholder group interest in promoting disclosure in the contractual relationship.

${ }^{61}$ See Holmes, supra note 16, at 382, n.3.

${ }^{62}$ See Klott v. Assocs. Real Estate, 322 N.E.2d 690, 692 (Ohio Ct. App. 1974) (noting a “a duty imposed by law to speak" in the presence of "a dangerous latent defect in the property not readily discoverable by the vendee. By way of example, if there be a contaminated well, known to the vendor and undisclosed to the vendee, the concealment of such may well constitute actionable fraud."); see also Holman v. Howard Wilson Chrysler Jeep, Inc., 972 So.2d 564, 568 (Miss. 2008) ("The duty to disclose is based upon a theory of fraud that recognizes that the failure of a party to a business transaction to speak may amount to a suppression of a material fact which should have been disclosed and is, in effect, fraud.").

${ }^{63}$ See Stewart v. Wyoming Cattle Ranche Co., 128 U.S. 383, 388 (1888) (noting that if a party "fraudulently produc[es] a false impression upon the mind of the other party ... it is unimportant whether the means of accomplishing it are words or acts of the defendant, or his concealment or suppression of material facts not equally within the knowledge or reach of the plaintiff.").

${ }^{64}$ See Hays v. Meyers, 107 S.W. 287, 289 (Ky. 1908) (noting that "there are times and occasions when it is the duty of a person to speak in order that the party he is dealing with may be placed on an equal footing with him as when the knowledge he possesses is not within the fair and reasonable reach of the other").

${ }^{65}$ See Stewart v. Phoenix Nat'l Bank, 64 P.2d 101, 106 (Ariz.1937) ("It is the general rule of law that, where a relation of trust or confidence exists between two parties so that one of them places peculiar reliance in the trustworthiness of another, the latter is under a duty to make a full and truthful disclosure of all material facts.").

${ }^{66}$ U.S. Concord, Inc. v. Harris Graphics Corp., 757 F.Supp. 1053, 1057 (N.D.Cal. 1991) ("[A] duty to disclose arises when one party possesses superior knowledge not readily available to the other and that party knows the other is acting on the basis of mistaken knowledge.”); see Janel World Trade, Ltd. v. World Logistics Servs., Inc., 2009 WL 735072 (S.D.N.Y. 2009), at *10 ("A duty to disclose between negotiating parties arises... where one party has superior knowledge of certain information, that information is not readily available to the other party, and the first party knows that the second party is acting on the basis of mistaken knowledge" (internal quotation marks omitted)). 


\section{Precontractual Disclosure in Marine Insurance Contracts}

Both American and British courts have deviated from the general rule by imposing precontractual disclosure in certain insurance contracts. More specifically, in marine insurance contracts, court decisions have held that parties must disclose material facts before the insurance contract is in place. This requirement allows contracting parties to void contracts completely if the other party fails to disclose material facts prior to contract execution, regardless of intent. Despite the lack of a scienter requirement and the potentially harsh consequences, courts have largely fallen in line to develop a fairly reliable definition for the doctrine: a material misrepresentation or omission, whether or not in response to a specific inquiry, renders the insurance contract voidable. The marine insurance industry has been subject to this requirement of precontractual disclosure for nearly two and a half centuries. ${ }^{67}$ Initially, this requirement was justified under the concept of uberrimae fides, ${ }^{68}$ or utmost good faith, first established in Carter $v$. Boehm. ${ }^{69}$

Carter involved Fort Marlborough, a structure built by the British East India Company on the island of Sumatra, Indonesia. ${ }^{70}$ The fort's governor, Mr. Carter, wary of an attack by French forces, purchased an insurance policy from Mr. Boehm against "being taken by a foreign enemy." "71 The fort was, in fact, later taken by a French expeditionary force. ${ }^{72} \mathrm{Mr}$. Carter attempted to collect on the policy, and Mr. Boehm balked, arguing that $\mathrm{Mr}$. Carter was aware that the fort was not "designed to resist European enemies" (i.e., the French) but was "only calculated for defen[se] against the natives of the island of Sumatra." 73 Mr. Boehm argued that this fact should have been disclosed. ${ }^{74}$

${ }^{67}$ The requirement was born in common law and later codified in various statutes. E.g., British Marine Insurance Act of 1906, 6 \& 7 Edw., c. 41.

${ }^{68}$ Other spellings that have appeared in court decisions are "uberrima fides" and

"uberrimae fidae." See Holmes, supra note 16, at 105.5 n.624.

${ }^{69}$ Carter v. Boehm (1766) 97 Eng. Rep. 1162.

${ }^{70}$ Id. at 1163.

${ }^{71} I d$. The policy was actually entered into by the governor's brother, on behalf of the governor.

${ }_{72}$ Id. at 1163 . Rather dramatically, the court noted that " $[\mathrm{t}]$ he event happened: the fort was taken by Count D'Estaigne, within the year." The Court noted that a "French man of war" overtook the fort with "64 guns and a frigate of twenty guns." Id. at 1166.

${ }^{73} I d$. at 1166 . The court noted that it was "proved without contradiction" that the fort was "not established for a place of arms or defen[s]e against the attacks of a[] European enemy; but merely for the purpose of trade, and of defen[s] e against the natives."

${ }^{74}$ Id. Presumably, the French boasted more advanced weaponry. 
The Carter court, applying utmost good faith, ${ }^{75}$ held that Mr. Carter was obligated to disclose all facts that would materially affect the risk taken by Mr. Boehm, ${ }^{76}$ even in the absence of fraudulent intent or knowledge. ${ }^{77}$ The court held that such disclosure would have included the fort's insufficient defenses and should have been communicated before the insurance contract was in place. ${ }^{78}$ Thus, the Carter court imposed a precontractual duty to disclose material facts in marine insurance contracts. ${ }^{79}$ This precontractual duty has survived to this day. ${ }^{80}$

Not unlike other areas of jurisprudence, American courts adopted the British common law imposition of precontractual disclosure in marine insurance contracts. The first definitive statement on the doctrine of utmost good faith in American jurisprudence was the Supreme Court's decision in the case of McLanahan $v$. Universal Insurance Co ${ }^{81}$ In McLanahan, the court assertively states that " $[\mathrm{t}]$ he contract of insurance has been said to be a contract uberrimae fidei, and the principles which govern it, are those of an

${ }^{75}$ Curiously, the court's opinion does not mention either "uberrimae fidei" or "utmost good faith." However, the Carter opinion is widely held to have hinged upon the doctrine. See, e.g., John Lowry, Wither the Duty of Good Faith in UK Insurance Contracts, 16 CONN. INS. L. J. 97, 107 (2009) (noting that "[i]t is striking that throughout [the court's] judgments on the issue of non-disclosure [, the court] avoided the terminology of 'utmost' good faith. Yet section 17 of the Marine Insurance Act 1906, the preamble of which declares it to be a codifying statute, states that insurance is uberrimae fidei.").

${ }^{76}$ Carter, 97 Eng. Rep. at 1164. ("The policy is void because the ris[k] run is really different from the ris[k] understood and intended to be run, at the time of the agreement.").

${ }^{77} \mathrm{Id}$. at 1164 ("[a]lthough the suppression should happen through mistake, without any fraudulent intention, yet still the [insurer] has been deceived"). At first blush, this duty may appear to place an undue burden upon the insured, as the insurer appears to bear no duty to investigate. However, later cases clarified that an insurer has a duty to investigate and may not rely upon unreasonable ignorance. See, e.g., Noble. v. Kennoway (1780) 99 Eng. Rep. 326, 327 ("Every [insurer] is presumed to be acquainted with the practice of the trade he insures... If he does not know it, he ought to inform himself.").

${ }^{78}$ Carter, 97 Eng. Rep. at 1164 ("The special facts ... lie most commonly in the knowledge of the insured only; the under-writer trusts to his representation, and proceeds upon confidence that he does not keep back any circumstance in his knowledge.... The keeping back such circumstance is a fraud, and therefore the policy is void.").

${ }^{79}$ See Lowry, supra note 75 , at 104.

${ }^{80}$ Although the court intended the standard of utmost good faith to apply in all commercial transactions, later decisions limited the duty to the marine insurance industry. See Lowry, supra note 75, at 98 (noting that the Carter court "was at the time attempting to import into English commercial law the civil law notion of good faith, but this ultimately proved unsuccessful and only survived for a very limited class of transactions.").

${ }^{81} 26$ U.S. 170, 185 (1828); see also Columbian Ins. Co. of Alexandria v. Lawrence, 27 U.S. 25, 29 (1829) (noting that "fair dealing requires that [the insured] should state everything which might influence, and probably would influence the mind of the [insurer] in forming or declining the contract."). 
enlightened moral policy." ${ }^{\prime 82}$ In imposing a precontractual duty to disclose facts, the McLanahan court followed the Carter court's refusal to impose a scienter requirement, and noted that "even if there be no intentional fraud, still the underwriter has a right to a disclosure of all material facts ... and the omission is fatal" to the contract. ${ }^{83}$

The following sections will reveal that if the Disclosure Framework were in use at the time of the Carter decision, the court's analysis would result in the same outcome. This is because (i) the information asymmetry analysis of the Disclosure Framework mirrors the Carter court's concerns about the actions of the parties and (ii) the stakeholder analysis reveals that the harm of mandated disclosure upon Mr. Carter is much lower than the harm of nondisclosure suffered by the stakeholder group.

\section{The Marine Insurance Information Asymmetry Analysis}

Under the Disclosure Framework, information asymmetry will only give rise to precontractual disclosure obligations if parties to the transaction do not have equal access. Equal access is satisfied when each party has an equal probability of discovering the information if such party were to expend the same level of effort. ${ }^{84}$

The lack of equal access to facts was a primary motivating factor for the imposition of precontractual disclosure in Carter. Indeed, in the insurance market, the insured often enjoys near exclusive access to the pertinent information: the goods to be insured. ${ }^{85}$ This is a concern of the Carter court, as reflected by the court's assertion that precontractual disclosure is appropriate when the facts to be disclosed "lie most commonly in the knowledge of the insured only." 86 In Carter, a letter which foretold the

${ }^{82}$ McLanahan, 26 U.S. at 185.

${ }^{83} \mathrm{Id}$.

${ }^{84}$ See SCHEPPELE, supra, note 43.

${ }^{85}$ Similarly, the reinsurance market imposes a precontractual duty to disclose material information regarding the reinsured's risk because "[t]he knowledge of the risk, both in the disclosure of material information used to set the premium, and in the actual administration of the contract, lies with the ceding insurer" (as opposed to the reinsurer), See Steven W.

Thomas, Utmost Good Faith in Reinsurance: A Tradition in Need of Adjustment, 41 DUKE L. J. 1548, 1557-58 (1992)

[t]he absence of utmost good faith within the reinsurance market [would] spawn increased costs as reinsurers are forced either to hire their own investigative teams to verify and thus to duplicate the assessment of the risk by the ceding insurers, or to increase premiums to cover greater risk. Reinsurers and ceding insurers have depended on the principle of utmost good faith ... to prevent wasted supplication of effort that would result in higher premiums.

${ }^{86}$ Carter, 97 Eng. Rep. at 1164. 
French attack was in the sole possession of the insured and was not disclosed to the insurer. ${ }^{87}$ In addition to predicting the French attack, this letter admitted a "weakness of the fort," noted that the fort was "badly supplied with stores, arms, and ammunition," and expressed concern that it would not withstand an attack from a "European" enemy. ${ }^{88}$ The Carter court held that this information, being in the sole possession of the insured, should have been disclosed to the insurer prior to the contract's execution. ${ }^{89}$ The Carter court stresses the reliance of the insurer (the information-poor party) by noting that the insurer "trusts [the insured's] representation, and proceeds upon confidence that [the insured] does not keep back any circumstance in [the insured's] knowledge.",90

Given these facts, it is clear that the insurer did not enjoy equal access to the information. While a modern reader may not have much sympathy for the insurer, it is important to remember that both transportation and communication were far more difficult in $18^{\text {th }}$ century England. Many marine insurance contracts covered "cargo or ships that were often at distant ports." ${ }^{91}$ Insurers, therefore, could not feasibly investigate the subject matter of an insurance policy absent a significant investment of both money and time. To discover this information, the insurer would be forced to deploy an investigator to travel a great distance by both land and sea to establish that the doomed fort was as represented by the insured. A requirement that the insurer personally inspect insured property, if not impossible, would in the very least impose a great expense upon the insurer. ${ }^{92}$ This expense is certainly greater than the expense the insured would expend to discover the fort's lacking defenses. Indeed, the insured's expense is negligible, as the insured knew of such facts by simply receiving and reading the undisclosed letter. Thus, in Carter, the insurer did not enjoy equal access to the information to be disclosed because if both Mr. Carter and Mr. Boehm expended an identical amount of energy, the Mr. Carter would have a much higher probability of discovering the fort's insufficient defenses. The information asymmetry in the Carter decision is therefore high enough to satisfy the first factor of the Disclosure Framework.

${ }^{87} I d$. at 1166.

${ }^{88} I d$.

${ }^{89} \mathrm{Id}$.

${ }^{90} I d$. The Carter court emphasizes the importance of accessibility by noting that "[t]he insured need not mention what the under-writer ought to know." Id. at 1165.

${ }^{91}$ See Thomas, supra note 85 , at 1555.

${ }^{92}$ Certain Underwriters at Lloyds, London v. Inlet Fisheries Inc., 518 F.3d 645, 646 (9th Cir. 2008) (noting that "The doctrine of uberrimae fidei was ... an economic necessity where insurers had no reasonable means of obtaining this information efficiently, without the ubiquity of telephones, email, digital photography, and air travel."). 


\section{The Marine Insurance Stakeholder Analysis}

The first step in the stakeholder analysis is the identification of potential stakeholders, or those with an interest in imposing precontractual disclosure in marine insurance contracts. In Carter, Mr. Boehm, the insurer, has an obvious interest in imposing precontractual disclosure (illustrated most convincingly by the fact that nondisclosure was the basis of Mr. Boehm's defense). ${ }^{93}$ Mr. Boehm is therefore a stakeholder. Given that the Carter decision imposed the duty of precontractual disclosure on all marine insurance contracts, ${ }^{94}$ one may also justifiably identify any potential insurer to a marine insurance contract as a stakeholder. Further, although it may appear that insureds do not have an interest in imposing precontractual disclosure (as the burden of disclosure will fall upon their shoulders), insureds who do not wish to conceal any facts from their insurers have an interest in imposing precontractual disclosure because it will result in lower premium costs. This is because any undue costs expended by the insurer (including costs of paying for destruction of ill-defended forts) will likely result in higher premiums for such customers. ${ }^{95}$ The stakeholder identification process does not end at this point, as there are additional parties directly affected by the court's mandate. Anyone who has a stake in the economic health of the insurance company (owners, shareholders, members, etc.) would also have a direct stake in requiring precontractual disclosure to avoid the insurance company's payment of unanticipated losses (e.g., losses sustained by ill-defended forts).

At this point, it may appear that the stakeholder identification process is quite broad. One obvious concern is that an identification of a high number of stakeholders will inevitably result in a high stakeholder cost and the Disclosure Framework analysis will always result in imposition of precontractual disclosure. To allay this concern, please note that the remaining exceptions discussed in this section reveal a much more limited stakeholder group. Further, the second step in the stakeholder analysis serves as the limiting factor. This step weighs the costs of nondisclosure suffered by the stakeholder group against the costs suffered by the party forced to disclose. In the marine insurance context, the potential costs of

93 See Carter, 97 Eng. Rep. at 1906.

${ }^{94} \mathrm{Id}$.

${ }^{95}$ See Reed Abelson \& Nina Bernstein, Health Insurers Push Premiums Sharply Higher, N.Y. TIMES (Sept. 27, 2011) (noting that insurance companies defending rising premiums because "the use and price of medical services have continued to rise in individual and small-group plans, in part because those policies tend to have a higher proportion of people with serious illnesses."). 
nondisclosure to the stakeholder group include either (i) the costs incurred by the insurance company sending an agent to inspect the fort to discover any material issues, or (ii) the insurance company being forced to pay for unanticipated damages suffered by the fort. On the other hand, if precontractual disclosure were imposed, the fort's inadequate defenses would be discovered, the individual insured's insurance premium will be increased, ${ }^{96}$ and the stakeholder group would avoid any economic harm. ${ }^{97}$ The costs to the stakeholder group have a much higher potential ceiling (the economic harms of paying the unanticipated loss, rising insurance premiums, and increased costs of inspection) than the potential costs to the insured (the higher premium for the individual). Therefore, the stakeholder analysis suggests that imposing precontractual disclosure is appropriate.

\section{B. A Federal Statutory Exception to the General Rule}

As noted in the previous section, there is a well-established common law exception imposing a duty of precontractual disclosure in certain contractual relationships, and the circumstances of this exception are in harmony with the Disclosure Framework analysis. In addition to common law, there are many instances in which the federal government has imposed similar duties. ${ }^{98}$ This section will discuss one specific instance: the regulation of private securities sales. The following section will examine the justifications for the precontractual disclosure mechanism in the sales of private securities and demonstrate how the mechanism satisfies the Disclosure Framework analysis.

\section{The Regulation of Private Sales of Securities}

Throughout the late $19^{\text {th }}$ century and the early decades of the $20^{\text {th }}$ century, business financing in America grew at an erratic and unsustainable pace. ${ }^{99}$ Although warnings existed, ${ }^{100}$ proposed federal regulations were

\footnotetext{
${ }^{96}$ Or more likely, the fort would not have been insured.

${ }^{97}$ A member of the stakeholder group could cancel the insurance and select a different insurance carrier. However, this creates more inefficiency, as every person required to buy insurance would be required to inquire as to the company's investigatory policies.

${ }^{98}$ See Palmieri, supra note 5, at 213 (noting that "[s]ome statutes require disclosures in certain contexts" (citing the Securities Act of 1933 (15 U.S.C. $§ 2 A$ ), the Truth in Lending Act of 1968 (15 U.S.C. $\S \S 1601-1667$ e), the Equal Credit Opportunity Act (15 U.S.C. $\S$ 1691 et. seq.), the Real Estate Settlement Procedures Act (12 U.S.C. 2601 et. seq.), the Interstate Land Sales Full Disclosure Act (15 U.S.C. 1701 et. seq.), the Truth in Negotiations Act (10 U.S.C. § 2306a), and the Magnuson-Moss Warranty Federal Trade

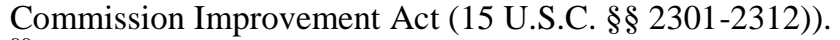

99 Joel Seligman, The Transformation of Wall Street: A History OF the
} 
unpopular and garnered little support. ${ }^{101}$ Left unregulated, the United States securities markets virtually collapsed in what is commonly known as the Great Depression. ${ }^{102}$

The effects of the Great Depression were both far-reaching and devastating and need not be reiterated here. The response to the crisis, however, is of great interest to this article. The Great Depression has been described as a "plague so sweeping that it altered expectations about the proper relationship of law to society,"103 and "sorely tested old assumptions" of the superiority of "voluntary rather than governmental regulation." 104 Thus, one imagines a fertile ground for regulation. Given this environment, one might expect-indeed, one might demand-a proportionally comparable paradigm-shifting response. The response, though manifold, was primarily to impose disclosure requirements ${ }^{105}$ before a security is sold (i.e., precontractual disclosure) through the Securities Act of $1933^{106}$ and

SECURITIES AND EXChANGE COMMISSION AND MOdERn CORPORATE FINANCE, 2 (1995) (noting that "[f]rom 1920-1928, 'prices on the New York Stock Exchange had approximately doubled' and "corporate profits ... rose over 80 percent").

${ }^{100} I d$. at 3 (noting that "[a]s early as 1925, [President] Hoover had been concerned about the growing tide of speculation .... and complained to President Coolidge about the Federal Reserve Board's easy money politics. But at the time, Hoover did not care to press such views too firmly. Calvin Coolidge had achieved substantial popularity not by criticizing the booming economy, but by identifying himself with it.").

${ }^{101}$ Seligman, supra note 99, at 2 (noting that "a majority of the country's voters had supported laissez-faire economic policies suggested by Calvin Coolidge's often-quoted remark 'This is a business country ... and it wants a business government").

${ }^{102} I d$. at $1-2$.

Between September 1, 1929, and July 1, 1932, the value of all stocks listed on the New York Stock Exchange shrank from a total of nearly $\$ 90$ billion to just under $\$ 16$ billion - a loss of 83 percent. In a comparable period, bonds listed on the New York Stock Exchange declined from a value of $\$ 49$ billion to $\$ 31$ billion. ... During the postWorld War I decade, approximately $\$ 50$ billion of new securities were sold in the United States. Approximately half or $\$ 25$ billion would prove near or totally valueless."

${ }^{103}$ Kermit L. HALl and Peter Karsten, The Magic Mirror: LAw in AMERICAN HISTORY, 290 (2009).

${ }^{104} \mathrm{Id}$.

${ }^{105}$ Disclosure, viewed by some as a "conservative response" to the Great Depression, was the primary tool of the Securities Acts. See Seligman, supra note 99 at 29. Championed by President Roosevelt, the required disclosure was intended to ameliorate the information imbalance between a security's buyer and seller. In endorsing the Securities Acts, Roosevelt emphasized the importance of the disclosure requirements, noting that every sale of securities "shall be accompanied by full publicity and information, and that no essentially important element attending the issue shall be concealed from the buying public." Message to Congress on Federal Supervision of Investment Securities (Mar. 29, 1933), in 77 CONG. REC. 937 (1933).

${ }^{106} 15$ U.S.C. $§ 77 \mathrm{a}-\mathrm{bbbb}$. 
the Securities Exchange Act of 1934. ${ }^{107}$ The bulk of the disclosure requirements of these statutes concern companies that sell securities on the open market (because such companies are generally large, the trading activity of such companies is great, and the lack of regulation of such companies was the primary reason for the Great Depression). ${ }^{108}$ However, this article is more interested in the regulation of securities sales by private companies (i.e., those that do not offer shares on the open market).

The focus on private securities is because the requirements of the securities laws for such sales attempt to balance seemingly inconsistent goals: loosening restrictions on private companies and maintaining protections of potential investors. The sale of securities ${ }^{109}$ by private companies is regulated by Rules 504, 505, and 506 of Regulation D. ${ }^{110}$ In the interest of brevity, this article will restrict its discussion to issuances under Rule 506, the most popular exemption. ${ }^{111}$

${ }^{107} 15$ U.S.C. $§ 78$ a-pp; Seligman, supra note 99, at 39 ("“A] primary enduring mission of the SEC has been to compel disclosure of data by firms involved in securities markets.... [T] his policy has become so well established, it is generally regarded as the appropriate or inevitable method of regulating corporate finance.").

${ }^{108}$ See 15 U.S.C. $\$ \S 77 \mathrm{f}$ (requiring registration with the SEC before an issuer may sell any securities to the public. This registration is intended to "provide investors with full disclosure of material information concerning public offerings of securities in commerce.”); Wasson v. SEC, 558 F.2d 879, 886 (1977) (citing Ernst \& Ernst v. Hochfelder, 425 U.S. 185, 195 (1976)).

${ }^{109}$ Due in part to the overwhelming regulatory influence of securities laws in this area, one may fail to consider the sale of a security as a contractual relationship. However, this relationship is, in essence, a contract governing one party's purchase of a good from another party.

${ }^{110} 17$ C.F.R. $\$ 230.501$. These rules were promulgated by the SEC under the power granted by Section 3(b) of the Securities Exchange Act of 1934, which authorizes the SEC to exempt any certain offerings from regulation if the SEC "finds that the enforcement ... with respect to such securities is not necessary in the public interest and for the protection of investors by reason of the small amount involved or the limited character of the public offering."

${ }^{111}$ Rutherford B. Campbell, Jr. Peter D. Fetzer, Terry D. Nelson, \& A. Michael Primo, THE BUSINESS LAWYER, The Wreck of Regulation D: The Unintended (and Bad) Outcomes for the SEC's Crown Jewel Exemptions (noting that "roughly 80 percent" of all private offerings are under Rule 506); See also The JOBS Act; Rule 506 Accredited Investor Only Offerings Likely to Be Even More Popular, MARTINDALE.COM (May 4, 2012), http://www.martindale.com/business-law/article_Foley-Lardner-LLP_1507198.htm (noting that Rule 506 offerings are the "most popular of the three types of non-registered offerings available under Regulation D" due to the "unlimited amount of funds that could be raised for such offerings and that state securities law registration requirements are preempted by federal law for such offerings"). Rule 506 is a safe harbor for the exemption provided under Section 4(2) of the Securities Act, which exempts "transactions by an issuer not involving any public offering." See 17 C.F.R. $\$ 230.506(a)$. Rule 506 was drafted to fall within this exemption, specifically noting that Rule 506 issuances "shall be deemed to be transactions not involving any public offering within the meaning of section 4(2)" of the 
Rule 506 allows a company to sell securities without registration with the Securities and Exchange Commission ("SEC") if the company abides by certain rules. ${ }^{112}$ Because registration with the SEC can, for many companies, prove prohibitively expensive, ${ }^{113}$ Rule 506 is popular among smaller companies looking to raise funds. ${ }^{114}$

Rule 506 treats sales of securities to accredited investors ${ }^{115}$ differently from sales to non-accredited investors. ${ }^{116}$ With respect to individuals, an accredited investor is generally a person with sufficient net worth to withstand a complete loss of the investment. ${ }^{117}$ If any purchasers are nonaccredited, then the issuer must both reasonably believe that each such nonaccredited investor has enough business experience to be capable of evaluating the investment, ${ }^{118}$ and, most importantly for this article, provide certain disclosures before the sale may be consummated. ${ }^{119}$

Securities Act. See 17 C.F.R. $\$ 230.506(a)$.

11217 C.F.R. $\S 230.506$.

${ }^{113}$ See Proposed Revision of Certain Exemptions from the Registration Provisions of the Securities Act of 1933 for Transactions Involving Limited Offers and Sales, Exchange Act Release No. 6339, 23 SEC Docket 446 (Aug. 7, 1981) ("The registration requirements of the Securities Act and the exemptive scheme therefrom have been criticized by commentators as disproportionately burdensome for small issuers.").

${ }^{114}$ See Rutheford B Campbell, Jr., The Wreck of Regulation D: the Unintended (and Bad) Outcomes for the SEC's Crown Jewel Exemptions, 66 Bus. LAW. 919, 921 (2011) (noting that "[w]ith regard to capital formation, Regulation D was based on the correct assumptions that transaction costs (offering costs) can throttle capital formation and that it is relative, not absolute, offering costs that are important in that regard)".

11517 C.F.R. $\$ 230.501$ (a).

${ }^{116}$ Net Worth Standard for Accredited Investors, Securities Act Release No. 9287, 2011 WL 6415435 at *2 (Dec. 29, 2011) ("One purpose of the accredited investor concept is to identify persons who can bear the economic risk of an investment in unregistered securities, including the ability to hold unregistered (and therefore less liquid) securities for an indefinite period and, if necessary, to afford a complete loss of such investment.").

11717 C.F.R. $\$ 230.501$ (a). Currently, sufficient net worth means a person with a net worth of over $\$ 1,000,000$ (not including the value of the individual's primary residence); or (iii) a person whose income exceeded $\$ 200,000$ in each of the past two years (or $\$ 300,000$ if combined with spouse's income).

11817 C.F.R. $\$ 230.506($ b)(2)(ii)

Each purchaser who is not an accredited investor either alone or with his purchaser representative(s) has such knowledge and experience in financial and business matters that he is capable of evaluating the merits and risks of the prospective investment, or the issuer reasonably believes immediately prior to making any sale that such purchaser comes within this description.

Note, however, that " $[\mathrm{m}]$ any commentators have expressed the view that it is impossible to evaluate an offeree's qualifications without providing the offeree basic information concerning the offering." See Securities Act Release No. 6339, 1981 WL 31063 at *21. 11917 C.F.R. $§ 230.502$ (b)(1) ("If the issuer sells securities under ... Rule 506 to any purchaser that is not an accredited investor, the issuer shall furnish the information 
If the proposed sale is to accredited investors, the company-issuer has some discretion on what information is provided. ${ }^{120}$ However, if the sale is to non-accredited investors, the company-issuer must provide financial information (in addition to certain other disclosures) prior to the sale. ${ }^{121}$ The breadth of the financial disclosures depends on the size of the offering, with larger offerings requiring more detailed disclosures. ${ }^{122}$ Because private companies are not required to register financial statements with the SEC, such information is not normally available to potential purchasers. ${ }^{123}$

The apparent impetus in promulgating Rule 506 was to provide an efficient mechanism for small businesses to raise money. In justifying the Rule 506 exemption, the SEC noted that small businesses comprise "a vital part of the American economy," and emphasized the need to "liberalize sales of restricted securities ... to make small offerings more viable."124 Rule 506 was therefore specifically designed to provide a "less costly method of raising capital" 125 in response to the need for small companies to raise funds without complying with the oppressive strictures of the various

specified in paragraph (b)(2) of this section.”). Accredited investors do not trigger such disclosure obligations because it is assumed "that accredited investors can fend for themselves without the protections afforded by registration and thereby satisfy the requirements of proposed Rule 506(b)(1) without a separate subjective determination by the issuer." Securities Act Release No. 6339, 1981 WL 31063 at *22.

${ }^{120}$ See Rule 506 of Regulation D, U.S. SEC. EXCH. COMM’N (Dec. 3, 2009), http://www.sec.gov/answers/rule506.htm ("Companies must decide what information to give to accredited investors, so long as it does not violate the antifraud prohibitions of the federal securities laws. But companies must give non-accredited investors disclosure documents that are generally the same as those used in registered offerings. If a company provides information to accredited investors, it must make this information available to non-accredited investors as well.")

${ }^{121}$ See 17 C.F.R. $\$ 230.506$

If the issuer sells securities under ... Rule 506 to any purchaser that is not an accredited investor, the issuer shall furnish ... at a reasonable time prior to the sale of securities ... [either (i)] The information required in Article 8 of Regulation S-X (Rule 210.8 of this chapter), except that only the issuer's balance sheet, which shall be dated within 120 days of the start of the offering, must be audited[; (ii)] The financial statement information required in Form S-1 (Rule 239.10 of this chapter) for smaller reporting companies[; or iii] The financial statement as would be required in a registration statement filed under ${ }^{122} I d$. the [Securities Act] on the form that the issuer would be entitled to use.

${ }^{123}$ See The Investor's Advocate, U.S. SEC. EXCH. COMM'N (July 30, 2012), http://sec.gov/about/whatwedo.shtml ("Companies that are privately owned are not required by law to disclose detailed financial and operating information. They have a wide latitude in deciding what types of information to make available to the public. They can shield information from public knowledge and determine for themselves who needs to know specific types of information."). 
federal securities laws. ${ }^{126}$ However, if the capital needs of small businesses were the only goal, the SEC would not have required disclosures of any kind. Although certainly less burdensome than registration with the SEC, the disclosure requirements of Rule 506 remain an imposition upon the small business issuer. By easing regulatory oversight through Rule 506, the SEC recognized that it created the potential for companies to take advantage of certain investors. The SEC's very existence is premised upon the fact that a laissez-faire approach to financial market regulation culminated in the Great Depression. ${ }^{127}$ Thus, although there is significant evidence that the promulgation of Rule 506 was driven by the federal government's desire to craft an efficient way for small businesses to raise funds, ${ }^{128}$ the issue of information asymmetry was also a primary motivation of the SEC. This is revealed in the Rule 506 deliberations, which cite "access to the same kind of information that registration would disclose" as a "primary consideration" for Rule $506 .{ }^{129}$ In fact, lack of access to information is the central motivating factor behind virtually all securities laws. ${ }^{130}$ Thus, it is not surprising that this issue was of utmost importance to the drafters of Rule 506. In sum, Rule 506's precontractual disclosure mechanism meets two seemingly contradictory goals: (i) easing capital-raising regulations on

${ }^{124}$ U.S. SEC. EXCH. COMM'N, 44th Annual Report of the SEC v, 16 (1978) (covering the public hearings held by the SEC to determine "the effects of [SEC] rules and regulations on the ability of small businesses to raise capital").

${ }^{125}$ Securities Act Release No. 6274, 1980 WL 25332 at *6.

${ }^{126}$ Rex Hurley \& Carla Green, Florida's Response to the Need for Uniformity in Federal and State Securities Registration Exemption Requirements, 12 FLA. ST. U. L. REV. 309, 313 (1984) (asserting that " $[\mathrm{t}]$ he underlying rationale expressed for these exemptions was that small businesses could not afford the burdensome transactional costs generally associated with complete registration").

${ }^{127}$ See Seligman, supra note 99, at 2 (noting that the hearings that eventually led to the enactment of federal securities laws and the establishment of the SEC were designed to combat the fact that the "majority of the country's voters had supported the laissez-faire economic policies" of Calvin Coolidge).

${ }^{128}$ Marvin R. Mahney, Regulation D: Coherent Exemptions for Small Businesses Under the Securities Act of 1933, 24 WM. \& MARY L. REV. 121, 166 (1982) ("In 1977, the Advisory Committee on Corporate Disclosure reported to the SEC that its 'survey of publicly held companies indicates that the burden of reporting weighs more heavily on small than large companies."(citation omitted)).

${ }^{129}$ Consideration of the Impact of the Small Business Investment Act of 1980 on Certain Exemptions from the Registration Provisions of the Securities Act of 1933, Securities Act Release No. 6274,1980 WL 25332 at*4 (Dec. 23, 1980) (internal quotation marks omitted) (citing SEC v. Ralston Purina Co., 346 U.S. 119 (1953).

${ }^{130}$ See Seligman, supra note 99, at 604 (noting that "[a]t its core, the primary policy of the federal securities laws today involves the remediation of information asymmetries. This policy most obviously applies with respect to the mandatory disclosure system, which compels business corporations and other issuers to disseminate detailed ... information when selling new securities to the public...."). 
small businesses and (ii) protecting the most vulnerable population of potential investors.

\section{The Private Sale of Securities Information Asymmetry Analysis}

The justifications for the promulgation of Rule 506 mirror the Disclosure Framework's information asymmetry concerns. As noted above, one of the primary motivating factors supporting the promulgation of Rule 506 was the desire to provide an efficient means of raising capital for small businesses. ${ }^{131}$ However, the SEC was only interested in making small business fundraising more efficient if it could do so without lessening the protection of the potential investors. ${ }^{132}$ To maintain such protection, Rule 506 imposes precontractual disclosure requirements to remedy information asymmetry between the company-issuer and the would-be investor. More specifically, the SEC drafted Rule 506 to protect those prospective purchasers of securities who are deemed most susceptible to harm, the nonaccredited investors. ${ }^{133}$ The disclosures help such person, the nonaccredited investor, through mandatory disclosure of financial information. By forcing companies to produce salient financial information, the nonaccredited investor is provided all the tools necessary to make an informed decision. Thus, the point of Rule 506 was to provide an efficient capitalraising device for small businesses that is as fair as possible for nonaccredited investors. ${ }^{134}$ These financial disclosures are designed to prevent the information-rich (the issuing company) from taking advantage of the information-poor (the would-be investor) by requiring the company to lay bare vital company-specific information.

${ }^{131}$ See supra notes $125-126$ and accompanying text.

${ }^{132}$ Consideration of the Impact of the Small Business Investment Act of 1980 on Certain Exemptions from the Registration Provisions of the Securities Act of 1933, Securities Act Release No. 6274, 1980 WL 25332 at *2 (Dec. 23, 1980) (emphasizing that any action that would "ease the impact of the federal securities laws on small business capital formation" must be "consistent with the protection of investors").

${ }^{133}$ However, note that unlike other exemptions, Rule 506 requires that "all non-accredited investors, either alone or with a purchaser representative, must be sophisticated - that is, they must have sufficient knowledge and experience in financial and business matters to make them capable of evaluating the merits and risks of the prospective investment." Rule 506 of Regulation D, U.S. SEC. EXCH. COMM'N (Dec. 3, 2009), http://www.sec.gov/answers/rule506.htm.

${ }^{134}$ It should be noted, however, that actual disclosures for sales of securities to nonaccredited investors are rare because such disclosures are costly. See Proposed Revision of Certain Exemptions from the Registration Provisions of the Securities Act of 1933 for Transactions Involving Limited Offers and Sales, Securities Act Release No. 6339, 1981 WL 31063 at *12 (Aug. 7, 1981). 
The information asymmetry analysis supports the imposition of such disclosure to achieve equal access to the pertinent information. It should be self-evident that in the issuer-investor relationship, the issuer does not have equal access to the company's financial information. If an investor wanted to obtain such information, such investor would have to contact the company and request (and potentially negotiate for) the disclosure of the information. This expenditure of effort is clearly greater than the effort that would have to be expended by the issuer, which would amount to no more than a phone call or email to the company's accountant. Thus, because the parties do not enjoy equal access to the information, the information asymmetry analysis tips in favor of imposing precontractual disclosure.

\section{The Private Sale of Securities Stakeholder Analysis}

The stakeholder analysis of the Disclosure Framework reveals a strong interest in imposing precontractual disclosure upon the private sale of securities. To identify the stakeholders at issue in the Rule 506 precontractual disclosure mandate, one must first look at the contract at issue. The contract is the sale of private securities and the parties to the contract are therefore the company desiring to issue such securities and the potential purchasers of such securities. The party with a strong interest in imposing precontractual disclosure is the potential investor. One might be tempted to include the owners of the small businesses, such as shareholders, because they are directly affected by the transaction. However, while these parties have an interest in the transaction, they do not have an interest in imposing precontractual disclosure (because they are the owners of the entity that will ultimately bear the costs of disclosure). Thus, the only stakeholder in this transaction for the purposes of the Disclosure Framework is the would-be investor.

The next step, weighing the respective harms of either disclosure or nondisclosure, reveals a strong interest in favor of mandating disclosure. If precontractual disclosure were not required in this transaction, nonaccredited investors would not receive the direct benefit of the regulation (the disclosure of financial statements) and would be forced to make the investment decision in the absence of full information. In other words, the potential harm is that the non-accredited investor, an individual whose net worth cannot sustain a complete loss of the investment, would enter into an uninformed investment decision. This is contrary to both notions of innate fairness and freedom of contract principles. Alternatively, if the disclosure requirements of Rule 506 are imposed, all non-accredited investors receive certain financial information of the issuing company and are therefore given the opportunity to make an informed decision regarding the investment. The 
harm to the company-issuer is the cost of disclosing financial information. This cost is not insignificant, but pales in comparison to the potential harm to non-accredited investors. Thus, the harms suffered by the disclosing party are outweighed by the potential harm to the stakeholder group, the non-accredited investors.

\section{A Statutory-Common Law Hybrid Exception to the General Rule}

American jurisprudence has imposed a duty of precontractual disclosure through both court decisions and promulgation of statutes. These mechanisms are not, however, mutually exclusive; and legislators do not hesitate to act in areas in which courts have spoken. This possibility is illustrated in the following discussion, which analyzes the precontractual disclosure mechanism for residential real estate transactions. This precontractual disclosure requirement was initially established in court decisions, with subsequent decisions imposing escalating duties upon sellers of residential real estate. In the midst of this, state legislatures enacted statutes to codify the ever-increasing pro-consumer decisions. This is therefore an example of where the Disclosure Framework might have provided a helpful mechanism for the legislature to take into account all relevant stakeholder interests before imposing precontractual disclosure.

\section{Precontractual Disclosure in Private Home Sales}

In many states, before a seller may convey non-commercial real estate to a buyer, the seller must disclose material information about such property. ${ }^{135}$ This information must be provided prior to the sale, and the potential buyer can either back out of the purchase or negotiate a different price. The first of these statutes was enacted in California, which provided the model for many of the states that followed. ${ }^{136}$

\footnotetext{
135 Alaska Stat. § 34.70.010-.200 (1994); CAL. CiV. CoDE § 1102-1102.15 (West 1995); Del. Code ANN. tit. 6, § 2570-2578 (1994); HAW. REV. STAT. § 508D-1 to -20 (1994); IDAHO CODE ANN. § 55-2501 to 2512 (1994); 765 ILL. CoMP. STAT. ANN. 77/1-99 (West 1995); IND. CODE ANN. $§ 24-4.6-2-1$ to .-13 (LexisNexis 1995); IowA CoDE r.558A.1-.8 (1995); KY. REV. STAT. ANN. § 324.360 (LexisNexis 1994); MD. CoDE ANN., Real Prop. § 10-702 (West 1995); Mich. COMP. LAws § 565.951-.966 (1995); Miss. CODE ANN. § 89-1501 to -523 (1995); NEB. REV. STAT. § 76-2 (1994); N.H. REV. STAT. ANN. § 477:4-c (1994); OHIO REV. CODE ANN. § 5302.30 (West 1994); OKLA. STAT. ANN. tit. 60, § 831839 (West 1995); OR. REV. STAT. § 105.465-.490 (1994); R.I. GEN. LAWS § 5-20.8-1 to -11 (1994); S.D. CODIFIED LAWS § 43-4-37 to -44 (1995); TENN. CODE ANN. § 66-5-201 to 210 (1995); TEX. Prop. Code ANN. § 5.008 (1995); VA. CODE ANN. § 55-517 to -525 (1995); WASH. REV. CODE ANN. § 64.06.005-.900 (West 1995); Wis. STAT. ANN. § 709.01.08 (West 1994).

${ }^{136}$ Robert M. Washburn, Residential Real Estate Condition Disclosure Legislation, 44
} 
California enacted two statutes to require disclosures prior the transfer of residential property: (i) California Civil Code $\S 1102.1$ (the "Disclosures Upon Transfer of Residential Property") ${ }^{137}$ and (ii) California Civil Code $\S$ 2079 (the "Duty to Prospective Purchaser of Residential Property") 138 (together, the "California Statutes"). The California Statutes require any seller or broker of residential real property ${ }^{139}$ to provide certain disclosures prior to consummating any sales contract. ${ }^{140}$ The required disclosures are detailed in a Real Estate Transfer Disclosure Statement, and include representations as to the existence and operation of appliances; ${ }^{141}$ the existence of harmful materials, including asbestos, radon gas, and lead paint; ${ }^{142}$ flooding, drainage, or grading problems; ${ }^{143}$ and even whether the home suffers from "[n]eighborhood noise problems or other nuisances."144 The required disclosures in the Real Estate Transfer Disclosure Statement were an attempt to identify the material facts that a reasonable buyer would want to know before entering into a contract. By requiring delivery of the disclosures before execution of a contract, ${ }^{145}$ the California Statutes provide the potential purchaser the opportunity to consider material facts about the property prior to entering into the contract. ${ }^{146}$ In other words, this is an example of a statute imposing precontractual disclosure upon a private transaction.

\section{Motivation for the California Statutes}

The California Statutes were enacted in direct response to an evolving common law that imposed an expanding duty upon sellers and brokers of residential real estate. ${ }^{147}$ Decisions across the country reflected the

DEPAUL L.R. 381, 410 (1995).

${ }^{137}$ CAL. CIV. CODE $§ 1102.1-1102.15$ (West Supp. 1994).

${ }^{138} I d$. at $\S \S 2079-2079.10$.

139 "Residential Real Property" is defined as more than one, but fewer than four, dwelling units. $I d$. at $§ 2079$.

${ }^{140} I d$. at $\$ 1102.1-1102.15$

${ }^{141} I d$. at $\$ 1102.6$

${ }^{142} I d$.

${ }^{143} \mathrm{Id}$.

${ }^{144} \mathrm{Id}$.

${ }^{145} I d$. at $\$ 1102.3(\mathrm{~b})$.

${ }^{146}$ If the seller provides the disclosures after execution of a sales agreement (including any material amendment to any disclosure given), the purchaser "shall have three days after delivery in person or five days after delivery by deposit in the mail, to terminate his or her offer by delivery of a written notice of termination...." See CAL. CIV. CODE §1102.3(b).

${ }^{147}$ Paula C. Murray, Aids, Ghosts, Murder: Must Real Estate Brokers and Sellers Disclose?, 27 WAKE FOREST L. REV. 689, 693 (1992) (noting that "[i]n direct response to the Easton decision, the California Legislature enacted two statutes in 1985 which defined 
judiciary's desire to effectively flip the duty to investigate real property from the buyer to the seller, ${ }^{148}$ and in many states, "the common law provide $[\mathrm{d}]$... causes of action for ... fraudulent nondisclosure of material defects." "The California Statutes were not intended to serve as "a replacement of the common law, " 150 but were rather an attempt to simplify the expanding common law disclosure requirements. ${ }^{151}$ These requirements, which outlined the duties of residential real property sellers and brokers, were laid out and justified in Easton v. Strassburger. ${ }^{152}$

In Easton, the California Court of Appeals imposed a duty upon real estate brokers to investigate and disclose material facts concerning residential real property to potential buyers. ${ }^{153}$ Prior to this decision, common law imposed upon a broker a duty to disclose known defects. ${ }^{154}$ Easton, however, went further to impose a duty to disclose all material defects, whether known or unknown. ${ }^{155}$ This includes the duty "to conduct a reasonably competent and diligent inspection of the residential property ... and to disclose to prospective purchasers all facts materially affecting the value or desirability of the property." 156 This duty to inspect, the court noted, was implicit in precedent. ${ }^{157}$ More specifically, the court held that prior case law "speaks not only to facts known by the [broker], but also and independently to facts that are accessible only to [the broker]."158

Because Easton imposed new duties upon real estate brokers, this decision predictably inspired a concerted effort by California's broker community to limit potential liability. ${ }^{159}$ This effort spurred the state legislature to enact the California Statutes to rein in the evolving common

the legal duty owed by a broker to a buyer and specified the types of disclosure that must be made to prospective purchasers"); see Robert M. Washburn, Residential Real Estate Condition Disclosure Legislation, 44 DEPAUL L.R. 381, 410 (1995).

${ }^{148}$ Regardless of state statute protection, the buyer has an incentive to investigate the property because "a purchaser who has completed an inspection is in a better position to establish the elements of reasonable reliance and causation." See id. at 405.

${ }^{149}$ Id. at 404.

${ }^{150}$ See CA B. An., S.B. 1377 Sen. (May 10, 1994) (noting that "the form disclosure was intended to assist sellers and realtors to comply with their duty of disclosure)"

${ }^{151} \mathrm{Id}$.

152199 Cal. Rptr. 383 (Cal. Ct. App. 1984).

${ }^{153}$ Easton, 199 Cal. Rptr. at 391.

${ }^{154}$ Robert M. Washburn, Residential Real Estate Condition Disclosure Legislation, 44 DEPAUL L. REV. 381, 387-88 (1995).

${ }^{155}$ Id. at 408 .

${ }^{156} \mathrm{Id}$.

${ }^{157}$ Cooper v. Jeyve, 128 Cal. Rptr. 724 (Cal. Ct. App. 1976); Lingsch v. Savage, 29 Cal. Rptr. 201 (Cal. Dist. Ct. App. 1963).

${ }^{158}$ Easton, 199 Cal. Rptr. at 388 (citing Cooper, 128 Cal. Rptr. at 724).

${ }^{159}$ Id. at 409. 
law (thereby limiting the liability and duties of brokers). ${ }^{160}$

\section{The California Statutes and the Disclosure Framework}

The precontractual disclosure obligation imposed by the California Statutes is in harmony with the Disclosure Framework. However, the first step of the Disclosure Framework, measuring information asymmetry, is barely satisfied. Absent the requirement of precontractual disclosure, homebuyers would be forced to conduct a detailed investigation of the potential home. The imposition of precontractual disclosure places the burden of identifying and communicating material facts concerning the property upon the seller or the broker (i.e., party that has the best access to such facts). Given the imbalance of access to the house, if both parties were to expend identical effort into investigating the house, the sellers and brokers enjoy a slight advantage over the buyers. There is therefore information asymmetry in this relationship, but it is not great.

The second step of the Disclosure Framework, the stakeholder analysis, reveals that the only stakeholder in this transaction is the potential buyers of residential real estate. This is because the only interest that matters for the stakeholder analysis is the interest in imposing precontractual disclosure. Neither sellers nor brokers have any interest in imposing precontractual disclosure, because precontractual disclosure would increase the burden of these parties. Initially, it might appear that the costs saved by the stakeholder group (the buyers) in imposing precontractual disclosure are virtually identical to the costs expended by the sellers or brokers, because either party would be forced to inspect the home. However, because a real estate broker will show a particular house to several prospective customers, and because a prospective buyer will likely view several different houses, the costs are much greater for the buyers over the course of the home buying experience. That is, absent the precontractual disclosure obligation, each potential home buyer would be required to engage in a detailed investigation of each home such buyer considers. Assuming there is more than one interested buyer, this results in numerous investigations of the same house. With the obligation placed upon the broker or seller, only one investigation per house is required, and the results of such investigation may be given to each interested potential buyer. This greatly increases the efficiency of the transaction and reduces the potential costs to the stakeholders, the potential home buyers.

\footnotetext{
${ }^{160}$ See Washburn, supra note 154.
} 


\section{APPLICATION OF THE DiSCLOSURE FRAMEWORK}

As illustrated by Section III, examples in which courts and legislators have deviated from the general rule against precontractual disclosure are in harmony with the Disclosure Framework. Thus, the Disclosure Framework enjoys both theoretical support (from the perspective of freedom of contract principles) and historical support. To illustrate the application of the Disclosure Framework in a prospective manner, this section will apply the analysis to the hypothetical student's conundrum described at the article's outset. This analysis will reveal that the student loan fact pattern satisfies both factors of the Disclosure Analysis. Through illustration of the application, this section will demonstrate how the Disclosure Framework operates to identify an appropriate imposition of precontractual disclosure while maintaining and supporting freedom of contract principles.

\section{A. The Student Loan Problem}

We can now turn to the hypothetical described at this article's outset. To summarize, a prospective student is trying to determine the financial implications of choosing one school over another. One of the schools provided a financial aid letter which outlined estimated expenses, the amount most students borrow to attend the school, the loan default rate of graduates, and an estimated monthly payment. Unfortunately, the other school did not provide a similar letter, and the student is left to compare financial aid packages without complete information

1. “[W]hen I graduate, I'm going to owe like $\$ 900$ a month. No one told me that." 161

This contractual relationship has become quite pressing of late. The total amount of student loan debt, $\$ 904$ billion as of the first quarter of $2012,{ }^{162}$ has eclipsed revolving debt ${ }^{163}$ and continues to grow at an annual rate of 13.9 percent. ${ }^{164}$ The size of these numbers becomes even more troubling when one considers the high delinquency rate of student loans. ${ }^{165}$ The sheer

${ }^{161}$ Andrew Martin \& Andrew Lehren, A Generation Hobbled by the Soaring Cost of College, N.Y. TIMES (May 12, 2012).

${ }^{162}$ FEDERAL RESERVE BANK OF NEW YORK, QUARTERLY REPORT ON HOUSEHOLd DEBT AND CREDIT (May 2012) [hereinafter REPORT].

${ }^{163}$ Kelly D. Edmiston, Lara Brooks \& Steven Shepelwich, Student Loans: Overview and Issues, THE FEDERAL RESERVE BANK OF KANSAS CITY COMMUNITY AFFAIRS DEPARTMENT 12 (August 2012).

${ }^{164}$ See REPORT, supra note 162.

${ }^{165}$ See Edmiston et al., supra note 163, at 4 (noting that "[d]elinquencies are very high 
magnitude of student loan defaults on private loans, as much as $\$ 8.1$ billion, is startling. ${ }^{166}$ Defaults and delinquencies carry a threat of potentially devastating consequences for the borrower.

If a loan goes into default, the entire unpaid amount of the loan immediately becomes due. Defaulted borrowers may be sued, tax refunds may be intercepted, and/or wages may be garnished. The defaulted borrower is responsible for paying collection fees, costs, court costs, and attorney fees. Defaulted borrowers can be denied a professional license. Eligibility for future loan deferments is withdrawn, as well as eligibility for other federal student aid under federal benefit programs. Finally, student loan delinquencies are reported to the major credit bureaus. ${ }^{167}$

Not surprisingly, this reality affects a borrower's spending, both because of the lack of discretionary funds and the lack of access to other credit (due to lower credit ratings). ${ }^{168}$ In addition to these financial pressures, the burden of carrying this debt has a psychological toll on both students and parents. 169

Beyond the impact on individuals, the issue of rising student loan debt is one which might have a broader economic impact. Although most economists believe that a collapse of the student loan system would not have "the same devastating impact as the mortgage crash" (despite the fact that the student loan system is "larger than credit card and other consumer debt"), ${ }^{170}$ experts note that the "dark cloud" of student debt hinders economic recovery. ${ }^{171}$

All of these issues might be more palatable if the students were entering into the student loan contracts in an informed manner. Unfortunately, this is not the case. First, student loan applications and award letters are both "complicated" and "difficult to compare."172 Financial aid award letters "vary greatly in both content and presentation" and any tools for students to assess the potential impact of a student loan are "complex and often

compared to delinquencies on many other forms of debt ... impair[ing] the credit of a substantial share of borrowers and prevent[ing] them from accessing other forms of student aid").

${ }^{166}$ See Press Release, supra note 3.

${ }^{167}$ See Edmiston et al., supra note 163, at 12.

${ }^{168}$ Id. at 7.

${ }^{169}$ Id. at 13 (noting the "overlooked aspect of individual student debt" of "the psychological burden" carried by delinquent borrowers).

${ }^{170}$ Martin \& Lehren, supra note 161.

${ }^{171} \mathrm{Id}$.

${ }^{172}$ See Edmiston et al., supra note 163, at 12. 
difficult to locate." 173

Perhaps most upsetting is the fact that many students turn to private loans before exhausting all available federal loans. ${ }^{174}$ Federal loans often carry lower interest rates and more flexible payment options, but according to a 2008 study, "students and parents often do not know the difference between federal and private loans." ${ }^{175}$ Assuming rational economic action on the part of students, were the students to realize that federal loans were available, they would not resort to the higher interest rates offered by private loans and credit cards. ${ }^{176}$

\section{The Shopping Sheet: A Potential Solution}

Despite the size and reach of the student loan problem, it is not a completely intractable predicament. In fact, a partnership between the Consumer Financial Protection Bureau ("CFPB") and the Department of Education has created a letter which provides the information described in the hypothetical. This letter, otherwise known as the "Shopping Sheet," not only contains information such as the average cost of attending the particular school, the school's graduation and retention rate, and the percentage of students who default on their federal loans, but also provides some perspective for such information. ${ }^{177}$ For example, a school's loan default rate is characterized as low, medium, or high. ${ }^{178}$ Thus, a default rate of $6.2 \%$ is not merely reported, it is put into context, and the student knows that a $6.2 \%$ default rate is about average. The graduation rate and the retention rate of the school is compared to other schools in a similar

${ }^{173}$ Id.

${ }^{174}$ Martin \& Lehren, supra note 161; see also Edmiston et al., supra note 163, at 12 ("Anecdotal reports" showing that "some students take on private loans while still eligible for subsidized federal loans." Private loans "are not guaranteed by the federal government or otherwise subsidized.").

175 Jenson, Carol A., Private Loan Counseling for Undergraduate Students: The Role of College Financial Aid Counselors (2008) (unpublished Ph.D dissertation, University of Nebraska).

${ }^{176}$ In addition to the evidence of financial harm suffered by students, there is circumstantial evidence of a strong public policy interest in the fact that the Dodd-Frank Act specifically required the CFPB to submit a report on private student loans. Dodd-Frank Act $\S 1077$ (a). This mandate required the CFPB to examine, among other issues, "the consumer protections available to private education loan borrowers, including the effectiveness of existing disclosures and requirements and borrowers' awareness and understanding about terms and conditions of various financial products. Dodd-Frank Act, $\S 1077$ (b).

177 See CONSUMER FIN. PROT. BUREAU, http://www.consumerfinance.gov/static/students/disclosure.pdf, (providing an example of the Shopping Sheet for a fictitious student considering a fictitious school).

${ }^{178} \mathrm{Id}$. 
fashion. ${ }^{179}$ Thus, the school's data are not merely conveyed, but are communicated in a meaningful and comprehensible manner.

Unfortunately, schools are not required to provide the Shopping Sheet. ${ }^{180}$ Legislators could ameliorate both the problem presented in the hypothetical and the problem of rising student debt generally by making the Shopping Sheet mandatory for all colleges and universities. In fact, Congress is currently considering taking this step. On May 24, 2012, Senators Al Franken, Tom Harkin, and Chuck Grassley introduced the "Understanding the True Costs of College Act," which would require all colleges and universities to use a disclosure letter similar to the Shopping Sheet. ${ }^{181}$ Given that Congress is currently considering whether or not it is appropriate to impose disclosure in this relationship, this fact pattern is a perfect opportunity to analyze the proposed disclosure requirement in light of the Disclosure Framework.

\section{B. The Disclosure Framework}

1. The Student Loan Information Asymmetry Analysis

Although some information provided on the Shopping Sheet is available to our hypothetical student through other means, much of the information is in the sole possession of the schools. Such information includes the median borrowing rate and the loan default rate. This data is virtually unobtainable without the school's cooperation because, in order to determine this information, one would have to identify all former students of the school that undertook student loans and contact each former student to collect the necessary data. Even if a list of former students were public, the endeavor would prove terribly time-consuming and inefficient.

Perhaps the most poignant evidence of information asymmetry concerns the fact that students are forced to obtain all relevant information from the school. According to the results of a CFPB collection of public comments, students expressed difficulty in obtaining "reliable information" regarding private student loans. ${ }^{182}$ Most student respondents reported that they were "dependent on the school's financial aid office for information on student loans," and many respondents "believed that the quality of information they

\footnotetext{
${ }^{179} \mathrm{Id}$.

${ }^{180}$ Schools are only required to provide a Shopping Sheet to veterans. See Exec. Order No.13,607 (April 27, 2012),. To date, ten schools have pledged to use the Shopping Sheet for non-veteran applicants. See Press Release, supra note 3.

${ }^{181}$ Press Release, Senator Al Franken, Sen. Franken Introduces Bipartisan Bill to Help Families and Students Understand the True Cost of College (May 24, 2012), http://www.franken.senate.gov/?p=press_release\&id=2093.

${ }^{182}$ Private Student LoAns, Consumer Fin. Prot. Bureau, 70, July 20, 2012.
} 
received was inadequate." 183 The fact that the students are dependent upon the schools to provide the information is evidence that there is an accessibility problem. ${ }^{184}$

Further, even when a student has some information, regardless of its veracity, it is presented in a confusing manner. As noted by the CFPB, " $[\mathrm{t}]$ oo often students receive financial aid award letters that are laden with jargon, use inconsistent terms and calculations, and make it unnecessarily difficult to compare different financial aid awards side-by-side."185 Ultimately, the result is that students enter into contracts which they do not understand. ${ }^{186}$ This problem is reflected in the Dodd-Frank Act, which specifically asked the CFPB to examine whether students "have access to information sufficient to provide them with assurances that private education loans are provided in accord with the Nation's fair lending laws and that allows public officials to determine lender compliance with fair lending laws." 187

Given these facts, it may be clear that the parties do not enjoy equal access to the information at hand without engaging in the information asymmetry analysis. However, the analysis also clearly shows a high level of information asymmetry. As a reminder, the information asymmetry analysis asks whether the parties would have an equal probability of discovering the facts if they expended the same amount of energy. If the answer is no, then there is information asymmetry great enough to continue to the second step of the Disclosure Framework. With respect to the student's effort to be expended, the effort is greatly increased by the fact that information is difficult or impossible to come by, and that any information received is presented in complicated or misleading fashion. In

${ }^{183} \mathrm{Id}$.

${ }^{184}$ A recent district court decision emphasizes the problem of relying upon facts provided by the school. Although the case involved graduate students, the information asymmetry is virtually identical to the undergraduate hypothetical. In this case, the plaintiffs, recent graduates of the Thomas M. Cooley Law School, sued the law school on the grounds that Colley provided misleading information regarding the percentage of Cooley graduates employed and the average starting salary for Colley graduates. The court, despite noting that Cooley's proffered statistics were "inconsistent, confusing, and inherently untrustworthy," held that "an ordinarily prudent person would not have relied" upon such statistics. The court chastised the plaintiffs for believing the statistics, and noted that the plaintiffs "should have approached their decision to enter law school with extreme caution given the size of the investment." Thus, the court suggested that statistics provided by a school should be viewed as suspect. Macdonald et. al. v. Thomas M. Cooley Law Sch., No. 1:11-CV-831 2012, WL 2994107 (W.D. Mich. July 20, 2012).

${ }^{185}$ See Press Release, supra note 3.

${ }^{186}$ Id. (noting that the CFPB has "heard from thousands of student loan borrowers who say that they simply do not understand what they signed up for").

${ }^{187}$ Dodd-Frank Act $\S 1077$ (a). 
comparison, the school's effort necessary to discover the facts to be disclosed is not insignificant (the costs of maintaining the data), but it is significantly less than the required effort of the student. In the very least, the school does not rely upon another party to either produce a list of former students or determine such students' contact information. In sum, the information asymmetry in the contractual relationship between prospective students and student loan lenders (acting through the schools) is sufficient to satisfy the first factor of the Disclosure Framework.

\section{The Student Loan Stakeholder Analysis}

Having established that the information asymmetry in this relationship satisfies the first step, the next step in the Disclosure Framework is identifying the stakeholders and weighing the relevant harms. First, one must identify the stakeholders, or the parties that are directly affected by the transaction who have an interest in imposing precontractual disclosure. The most obvious stakeholder is the potential party to the student loan contract: the student. However, this does not represent the entire universe of stakeholders, as in many cases, parents of students are directly affected by either co-signing on their child's student loans or taking out loans to support their child's education. ${ }^{188}$

Once the stakeholders group is identified, the next step is to consider the stakeholder group's interest in imposing precontractual disclosure. If precontractual disclosure is mandated-if, in other words, the Shopping Sheet is made mandatory for all schools-the clear beneficiaries would be students and parents. Students and parents would benefit by having the opportunity to make informed decisions concerning the amount and type of loans accepted. The parties harmed by mandated disclosure include the would-be private student loan lenders, as they will likely see a decrease of overall student loans. This is not only due to students opting not to attend schools they cannot afford, but also because more students would presumably opt for less-expensive federal student loans. The harm suffered by private lenders if precontractual disclosure were mandated (lowering the total potential loan pool) is significantly outweighed by the harms currently suffered by the other stakeholders (entering into ill-formed loan agreements and taking on excessive amounts of debt).

Further, there is a viable argument that the private lenders would reap

${ }^{188}$ Gail Marks-Jarvis, Parents' Student Loan Debt, ThE CHICAGo TRIBUNE (Apr. 30, 2012); see also Edmiston, supra note 163, at 3 (describing the PLUS Loans program, in which loans "are made to parents of ... students who have reached borrowing limits for Stafford loans," and noting that "[b]ecause of the limited credit histories of most students, co-signers are often required"). 
some benefit from mandated precontractual disclosure. Private lenders are currently facing over $\$ 8$ billion of student loan defaults, representing over 850,000 separate loans. ${ }^{189}$ This default rate is significant. If one were to combine this default rate with the fact that a significant portion of private student loan borrowers graduate without a job (and that those who are employed have jobs that do not pay enough to make loan payments), ${ }^{190}$ then there is reason to think that mandated precontractual disclosure would not harm private student lenders as much as the previous paragraph suggests. To be sure, there is a possibility of a lower total number of student loans issued, but this loss may be mitigated by a presumed reduction in the number of defaults. Regardless, the harm suffered by private lenders in mandating precontractual disclosure (lowering the total potential loan pool) is significantly outweighed by the harms currently suffered by the stakeholder group (entering into ill-formed loan agreements and taking on excessive amounts of debt).

\section{CONCLUSION}

Information asymmetry is virtually ever-present. In many cases, the use of information asymmetry to one's advantage is an inevitable symptom of a free market. But in some instances, information asymmetry is so great that it frustrates an individual's ability to privately order his or her contractual arrangements. Once information asymmetry rises to this level, the principles of a free market are endangered and it is appropriate to consider actions to lessen information asymmetry. Such actions are appropriate if the harm of nondisclosure outweighs the harm of disclosure. This is, in a nutshell, the Disclosure Framework.

A lawmaker's use of the Disclosure Framework will properly identify transactions in which mandating precontractual disclosure is appropriate. However, the Disclosure Framework's application need not be limited to use by legislators. Because the Disclosure Framework identifies instances in which mandating precontractual disclosure is both historically consistent and theoretically justified, the analysis may also provide a convincing argument for consumer protection groups to urge lawmakers to act. For example, if a student rights group wished to convince Congress to make the Shopping Sheet mandatory, the Disclosure Framework may provide a convincing argument that the Shopping Sheet's required disclosure is not

189 See PRIVATE STUDENT LOANS, supra note 182, at 5.

190 See Id. at 70 ("In 2009, the unemployment rate for private student loan borrowers who started school in the 2003-2004 academic year was 16\%. Ten percent of recent graduates of four-year colleges have monthly payments of all education loans in excess of $25 \%$ of their income."). 
only necessary, but appropriate for legislative action.

$$
* * *
$$

